\title{
THE CANADIAN NATIONAL ENERGY BOARD: ECONOMIC "JURISPRUDENCE" IN THE NATIONAL INTEREST OR SYMBOLIC REASSURANCE?
}

\author{
IAN MCDOUGALL*
}

The author of this article offers a comprehensive examination of the scope and practical effectiveness of national regulatory efforts with respect to the Canadian natural gas industry. The scope and power of the controls available to the National Energy Board, and the practical use made of them, have been described. After first setting out the general historical and political background to the passage of the National Energy Board Act in 1959, the author undertakes an examination of the NEB's general powers, advisory functions with respect to the Governor-in-Council, specific control powers over pipeline companies, import and export controls and the like. The Board's progress concerning the four major gas export complexes is appraised. This discussion is followed by detailed consideration of four major administration difficulties confronted by the regulators: the development of procedural criteria with respect to the calculation of "exportable surpluses", the protection of domestic gas markets vis-à-vis price structures, the determination and application of "just and reasonable" export pricing, and finally, the promotion and maintenance of mutually beneficial co-operative undertakings with the United States. It is generally submitted that the NEB, on the basis of its past performance, has proven itself unable to effectively discharge the enormous responsibility of giving effect to the national interests at stake. Its inability to solve problems relating to the uncertainty of reserve estimations and the rate at which the domestic market would expand are suggested as probable causes of this failure. Improved methods of calculating reserves, coupled with clarification of the Board's constitutional position, would do much towards alleviating some of the difficulties presently being experienced.

\section{INTRODUCTION}

The proposition to be tested by this paper can be summarized as follows:

It makes good economic sense to consider gas reserves in a continental manner and allow the development of those reserves to serve United States markets, as well as Canadian markets, at a reasonable cost. This benefits consumers [in the United States] by making additional reasonably priced long-term gas supplies available, and also benefits Canadians by enabling them to serve their markets at lower costs through more efficient utilization of facilities and also benefits Canada by developing regions of their country which otherwise would have no economic incentive for development.

This paper is concerned with three questions arising from the statement; namely, is it true, was it ever true, and what can be said, in light of this inquiry, about the effectiveness of past and present regulatory efforts in respect of the development of the Canadian natural gas industry?

Subject to a number of historical qualifications considered in Part II this paper adopts basically the null hypothesis: that U.S. natural gas market service has not demonstratably offered Canada the advantages referred to above. And it is further argued that this result testifies to the apparent inability of Canadian regulators to define and give effect to the national interests at issue. While the development, exploitation, and sale of natural gas has been used as the touchstone from which the relative success or failure of regulation can be judged, it is important to note a number of slight but unavoidable limitations inherent to the exercise from the onset. Chief among these is the assumption that the export of natural gas can be viewed in isolation from the development, utilization, and export of oil. It is an over-simplification which is, in

\footnotetext{
*B.A., LL.B., LL.M., Assistant Professor, Faculty of Law, Dalhousie University. This article was submitted as a
} Masters Thesis at Harvard Law School, 1972. 
reality, incorrect to the degree that gas finds often occur as a by-product of the search for oil. Historically much of the early Canadian gas development was a concomitant of oil production and the time period during which natural gas has enjoyed independent significance has been relatively brief indeed. Even though gas development has achieved independent importance beyond any doubt, it is nonetheless true that at an international level oil and gas often still tend to be lumped together. Current Canadian-American discussion over a "Continental Energy Package" is presumably concerned with a broad range of energy sources and does not contemplate individualized treatment of natural gas.

However, the degree to which natural gas should be treated as an independent commodity remains an open question. There are a number of factors which suggest that it should be, not only for the abstract purpose of assessing the workings of the National Energy Board, but also as a practical exercise in resource economics. First, natural gas is almost unique among Canadian energy resources for the simple reason that a domestic market may be capable, in the not-too-distant future, of absorbing all economically-accessible production. This is quite unlike coal which arguably exists in such vast quantities that the value of serving an export market is almost unassailable. As a consequence the onus upon the regulators in respect of natural gas development, and the long-term public interest, is substantial. A miscalculation as to reserves for example, could have rather profound effects upon future gas sales in Canada and energy prices generally. This in turn could impair anti-pollution efforts in Canadian urban areas, and significantly abbreviate the time-reliability of gas-fired energy capital. As a second point, the expanding domestic demand for natural gas (in relation to total economic supplies) has also served to make the present value of domestic reserves a less dubious calculus than is true of the other fuels. Large sales to external markets at low prices convey a much greater risk of tangible loss than is true, for example, of coal for the simple reason that the commodity being sold has, or will shortly have, an alternative employment domestically.

The paper is organized into five major headings. Part II outlines the main historical elements relevant to the present regulatory framework. Reference is made to early problems of depletion that occurred in relation to gas fields first developed around the turn of the Century and difficulties encountered in the Trans-Canada Pipeline development. The importance of governmental involvement is traced from its earliest beginnings through to the Borden Royal Commission on Energy in 1958. Part III is concerned with a description of the structure and jurisdiction of the on-going regulatory agency proposed by the Commission. Attention is focused upon the National Energy Board's broad range of powers and its somewhat inexplicit mandate in respect of its obligation to protect the "best interests" of Canadians. Parts IV and V consider the major export complexes, and the evolution of Board procedure with regard to the export question. Note is here made of the complexity of many of the considerations most germane to the issuance of licenses, and the resultant low profile of Board-industry dealings. It is suggested that so far as most Board procedure is concerned there is a measure of interested-party dominance owing in large part to the formidable technical threshold that bars public access, and to the dispersion of interests which pre-empts much public initiative. Achievement of the 
organization of resources necessary to match those of the industry, before the Board, is an additional deterrent to the growth of a tradition of public involvement. Reference has also been made to the Board's seeming reluctance to risk disturbing existing export terms that have been given prior sanction. In the final section of the paper a number of conclusions and recommendations have been tendered.

\section{EARLY CANADIAN PETROLEUM DEVELOPMENT AND ITS LESSONS}

The exploration and development of Canada's petroleum resources has long 1 laboured under three major handicaps: namely, wide geographical barriers between the country's most productive sedimentary basins $^{2}$ and domestic market areas, ${ }^{3}$ uncertainties in assessing future supplies ${ }^{4}$ and the rate of growth of domestic demand in a developing economy, ${ }^{5}$ and difficulty in establishing a system of comprehensive resource management in a federal state. ${ }^{6}$ Given these factors, it is perhaps no surprise that the Canadian petroleum industry has experienced a rather capricious evolution. The geographical obstacles have made domestic market service often an enormous investment. ${ }^{7}$ To the extent that the industry has been unable to rely upon more than just domestic market expansion, it has also been forced to assume the risk of substantial uncertainty; much more than has had its counterparts to assume in more highly-developed economies. ${ }^{8}$ The Canadian industry has also had to seek and ultimately depend upon a rather high degree of governmental support in respect of a range of factors. These have included internal market protection, ${ }^{9}$ the sanctioning of large exports, ${ }^{10}$ informa-

1 Insofar as natural gas is concerned development in Eastern Canada reached something of a peak in the 1890's. The Western Canadian Sedimentary Basin reserves did not come into their own as producers until the late 1940's and early 1950's. Even as late as 1920 consumption was confined to areas close to the gas fields owing to the high costs of long distance transmission facilities, and wastage was common as a result of oil operations with the associated gas frequency being flared at the wellhead.

2 See Appendix B, I.

3 See Appendix B, 11 .

- Supply or reserve assessment, as it respects natural gas has always been a rather complicated problem. The reasons that this is true today have been examined at some length at a later stage in the main body of the paper. But in the early stages of the industry's development in Canada supply uncertainty in the main derived from the fact that most gas exploited was found in association with oil pools. The natural gas industry's fate was, to a very large extent tied to the health of the latter industry which precipitated most of the major gas finds, and further made economic exploitations possible.

5 The problem here has been basically threefold. On the one hand the rate of increase of natural gas demands, assuming preference orderings in the Canadian energy market is fixed, requires some kind of judgment with respect to the future growth patterns of the economy. Allowing for a measure of price elasticity in this same market, and the possibility that substitutions can take place within the market, further complicates the projection of internal demand. When one adds to this already formidable process, refinement, and transmission of gas, which will both lower its market price and raise its quality, accuracy in the assessment process reaches a very high premium indeed.

6 Under the British North America Act property and civil rights are under provincial control and on this basis a province's regulation of petroleum resources has not been challenged, although the markets which they can be sold to is under extensive Federal control by virtue of the National Energy Board Act, S.C. 1955, c. 14. Conflict over such control is frequent as one might expect, for the simple reason that the national interest in slowing resource exploitation for future domestic use will on occasion produce short-term hardship for the province that could otherwise sell to the export market.

To illustrate, in 1950 twenty-four percent of Canadian industry spending was on transportation facilities, compared with a mere seven percent in the U.S. By 1955 the Canadian figure had dropped to ten percent and the U.S. figure rested at roughly three percent. See Davis, Canadian Energy Prospects, 144(1957), a study prepared at the request of the Royal Commission on Canada's Economic Prospects.

s So long as the Canadian industry depended upon export markets as a means of expanding, its position was gomewhat vulnerable to the extent that its bargaining strength may on occasion have been limited by the want of an alternative domestic market base that could absorb a significant proportion of production.

9 The reservation of the Eastern Canadian market for the Trans-Canada Pipeline is a case in point. See infra discussion in main text.

10 See infra discussion of Emerson exports and later discussion of the National Energy Board's statutory obligation in respect of exports. 
tion services, ${ }^{11}$ direct financial assistance in some cases, ${ }^{12}$ and the creation of needed pipeline facilities on at least one occasion. ${ }^{13}$

In the face of all these considerations, the role of petroleum exports assumed perhaps an exaggerated importance vis-a-vis the industry's development. The comparatively more substantial export market in the United States was in particular, in one sense, the needed "cushion"14 that would permit the industry to partially mitigate the risk factor inherent to Canadian market service. To the degree that the expanded market that resulted from an export component served this end, it also eased the burdens otherwise placed upon government by periodic business losses and failures ${ }^{15}$ in this nationally "sensitive" sector of the economy. There are of course, a myriad of additional considerations that enter into this calculus of industry development and the role of the export market (for example, influence of exports upon scale economies in the industry, ${ }^{16}$ factors crucial to exploration ${ }^{17}$ and discovery ${ }^{18}$ rates, etc.) but for the moment it is perhaps useful to limit the focus of the discussion to the major forces at play in the early development of Canadian gas reserves.

\section{The Trans-Canada Pipeline Debate}

Perhaps in no instance were the importance of the related factors of geographical impediments, market uncertainty, and government management better illustrated than in the case of the "great pipeline debate" which came to a head in 1956-1957.19 As of this time the bulk of Canadian oil and gas production was concentrated in the southern reaches of the Western Canadian Sedimentary basin. ${ }^{20}$ This enormous

11 This is a very significant portion of the National Energy Board's jurisdiction pursuant to its advisory functions under s. 22 of the Act. E.g., Energy Supply and Demand in Canada and Export Demand for Canadian Energy 1966 to 1990 , National Board (1969).

12 In May of 1956 the Government of Canada provided temporary financing on a short-term basis to TransCanada Pipe Lines Ltd. through the agency of the Northern Ontario Pipe Line Crown Corporation in order that Trans-Canada might complete the western section of the all Canadian facility.

13 A Crown corporation was jointly established between Ontario and Canada to acquire the required right of way and construct a line from west of Kenora eastwards for a distance of 675 miles to Kapuskasing, Ontario.

14 It should, however, be noted that the "cushioning" effect is of course true only if the export itself is profitable. As will be seen it is not always safe to assume that they will be. See infra Westcoast discussion under Exports.

15 Again, as the Westcoast case will show, this theory is not always borne out in reality.

${ }^{16}$ While it is undoubtedly true that exports do offer significant scale economies in those cases where export service is blended with domestic market service, very little empirical data exists on this subject in respect of the Canadian market. The Board reports and reasons for decisions concerning Westcoast and Trans-Canada (both of which have mixed domestic and export market areas) appear to deal with the questions as an article of faith more than as a subject of specific quantitative analysis.

17 The "conventional wisdom" with respect to exploration expenditure, and adopted by Canadian regulators, appears to be that it will increase in some fixed proportion to market and revenue (total) expansions. However, the analysis is somewhat marred in the case of natural gas for the simple reason that its discovery was, in the past, so often a spillover of oil exploration. As one authority noted in 1957 in this connection:

The oil industry, as now, will continue to turn up much of the gas. Some two-thirds of Canada's reserves will probably be found as a by-product of the search for oil. Much of our future supply, in other words, will be proven up without capital ever having to be raised specifically for this purpose.

See Davis, Canadian Energy Prospects, supra, n. 7 at 183. More recently there has been some suggestion that this situation has undergone a reversal; namely that oil has become the "by-product" of the search for gas, but to the extent that this phenomenon is a recent one it cannot lend justification to policies pursued as early as 1954. See also Dryden, Perspective on Alaska's Pipeline, The Geographical Magazine, Vol. XLIV. No. 4,1972 , at 226

18 The general rule with respect to discovery rates is of course that they must exceed the rate of growth of domestic demand in order to justify the allowance of an export. But more than this the economy of the incremental reserves should, as an affair of logic, be approximately equivalent to the economy of those being sold off.

19 The crisis associated with the project was a political one concerning the use of parliamentary closure to end the protracted debate which the project had provoked. The result in part was the defeat of the Liberal Government under Prime Minister St. Laurent in 1957.

${ }^{20}$ See Appendix B, I. 
region runs north-to-south roughly along the eastern slope of the Rocky Mountains, beginning at the Canada-U.S. frontier, and extending to the Mackenzie Delta in the Arctic. At the border it is approximately 860 miles wide, stretching to a point near to the eastern extremity of the province of Manitoba. Its shape is roughly triangular, narrowing progressively as one moves northwards.

In relation to Canadian markets these reserves were economically distant, ${ }^{21}$ although as time has shown, not insurmountably so. ${ }^{22}$ The major western Canadian market, British Columbia's Lower Mainland region, lay to the west of the Great Divide. ${ }^{23}$ The eastern industrial and population centres of Ontario and Quebec were an even greater distance away with the Pre-Cambrian Shield lying between them and the Alberta prairies.

Under these circumstances it was perhaps only logical for the industry, ${ }^{24}$ and the province of Alberta to look to oil and gas markets south of the border. The natural obstacles ${ }^{25}$ were less formidable, and the export market appeared to promise a more orderly development of western reserves with a few of the financial hazards otherwise involved in eastern market reliance. ${ }^{26}$ However, the total "locking-in" of domestic production to service a foreign market was not without its own risks, ${ }^{27}$ particularly at a time when domestic U.S. producers were pressing for protection of the U.S. market, ${ }^{28}$ and the Federal Power Commission (hereafter simply FPC) was in response reluctant to permit total de-

21 In respect of its transport natural gas has a number of distinct attributes that make it a much more costly product to "handle" than is true of oil. See Energy Supply and Demand in Canada and Export Demand for Canadian Energy 1966 to 1990 , supra, n. 11 at 59-60:

In contrast to oil and its products, gas is stored after production only in a limited way relative to production and consumption. By any given means of transport, the cost of moving a million Btu's is substantially higher for gas than for oil. In respect of pipelines, gas requires much higher investment in pipe and compressor facilities, and higher operation costs for compression and for storage, where the latter is used.

An important result of this relatively higher investment threshold to gas reserve development has been the requirement of long-term market stability. This has in turn had two observable effects. On the one hand it has made speculative investments in market supply in advance of demand very exceptional and reflective of the caution of the industry vis.a.vis risking large amounts of capital. On the other hand it has led to the use of long-term contracts between buyer and seller as contrasted with oil agreements which are comparatively speaking, of short-terms.

22 Notwithstanding the difficulties described, Trans-Canada's eastern natural gas market has proved to be enormously successful. Cf . Miller, Foreign Trade in Gas and Electricity in North America; a Legal and Historical Study, 114 (1970).

${ }^{23}$ See Appendix B, II. In addition, from a cost point of view it would seem likely that indigeneous B.C. discoveries would, ceteris paribus, have priority in this market.

24 Another factor of importance perhaps in this connection was the extent of U.S. ownership in the industry. For example in 1957 (after the west to east pipeline had been initiated) Davis noted, supra, $n$. 7 at 143 :

The Canadian oil industry consists mainly of large firms with important international connections-a state of affairs which is also true of petroleum operations in most other producing countries. Here 70 percent of the land under reservation or base and close to 80 percent of the presently proven oil reserves in the four western provinces are known to be in the hands of corporations owned and controlled in the United States.

See also Davis, supra, n. 7 at 163, for a discussion of the implications, as of 1957, of the parent-subsidiary trade in Canadian natural gas.

25 Even in those cases where the distance shipped to the south was equal to or in excess of the distance to Eastern Canada, the larger American market, with already-established inter-connecting pipeline facilities, and with more risk capital to devote to the creation of new facilities, was still the more attractive of the two.

${ }^{26}$ That is to say less investment capital (i.e., less risk) was needed to supply U.S. consumers in most cases.

27 The most important and perhaps most obvious of these was the decline in bargaining strength that was referred to supra, n. 8 .

28 Among the most active opponents to Canadian imports were the Texas Independent Producers and Royalty Owners Association or TIPRO. E.g., remarks of Commissioner John A. Carver, Jr., Federal Power Commission, before the 24th Annual Meeting of the Texas Independent Producers and Royalty Owners Association in Dallas, Texas, Monday, June 8,1970 , summarizes the history of this organization's involvement with respect to imports. 
pendence upon nationally-exogenous supply sources. ${ }^{29}$ In addition, the eastern Canadian energy market was becoming sizeable. By 1955, for example, it was having to import 323,000 barrels of crude daily ${ }^{30}$ to satisfy its burgeoning needs. This in turn meant that a significant portion of the Canadian economy became somewhat dependent upon stable import prices, which contributed to the growing federal concern ${ }^{31}$ that sufficient gas and oil pipeline links be established with internal reserve areas.

Two private west-to-east gas pipeline schemes emerged; one exportoriented and the other aimed primarily at the eastern market centres. The first scheme was that of Western Pipe Lines. ${ }^{32}$ Basically, the company proposed a Canadian route extending from the Alberta fields to Emerson, Manitoba via Winnipeg. From Emerson the pipe would be linked into the Minnesota and North Dakota markets. The second proposal was put froward by Canadian Delhi Oil which in 1951, had obtained a dominion charter for its wholly-owned subsidiary, Trans-Canada Pipeline Ltd. Trans-Canada was to in turn build an "all Canadian" facility extending as far east as Montreal. The initial reaction to this last plan was somewhat adverse in Alberta. The Company's removal permit applications were successively denied in 1951, 1952, and 1953 by the provincial agency, the Alberta Oil and Gas Conservation Board, ${ }^{33}$ and the project was for the moment frustrated. The debate and controversy between the two alternate plans thus continued over an extended period.

In 1954 Western Pipe and Trans-Canada were merged ${ }^{34}$ and, with the joining of the two companies, agreement was at last reached upon the "all Canadian" system. Sanction was obtained from the Alberta regulatory agency, with the issuing of the required removal permits in May of that year.

From the outset federal governmental support for the plan had been strong. Indeed there is some suggestion that the Department of Trade

${ }^{29}$ E.g., the FPC, 13 FPC (1959) at 221 stated:

Regardless of any long and cherished friendly relations with any neighbour nation able to supply such area with natural gas, it would not be in the public interest to permit the importation of its gas as the sole source. ... We do not consider it to be in the public interest . . to authorize a most important new project to serve a major area involving a large and important segment of the American economy which from the outset will be completely tied to and wholly dependent upon an exclusive source of supply entirely beyond the control of agencies of the United States.

See also Miller, supra, n. 22 at 100.102. The arguments of the U.S. producers were basically strategic: namely that imports were a threat to U.S. security in that domestic exploration was thereby discouraged and outside reliance concomitantly encouraged.

${ }^{30}$ Davis, supra, n. 7 at 100 . This was opposed to a 150,000 barrel import for the same market in 1949 .

31 The federal concern was two-fold. As was true in the United States, Canada also recognized the risks of becoming too dependent upon petroleum imports from foreign sources. But perhaps more importantly a west-to-east gas tie-in was also a means of reducing the equally risky situation of being too heavily dependent upon the export market in the U.S.

32 The company was incorporated by Special Act of the Parliament of Canada in 1949. Apart from director qualifying holdings no shares were issued by the company. Instead cash advances were made to the company from time to time by its sponsors known as the "Western Group" which consisted of the Calgary and Edmonton Corp. Ltd., Anglo.Canadian Oil Ltd., International Utilities Corp., Osler, Hammond and Nanton Ltd., Wood, Gundy \& Co. Ltd., and Nesbitt, Thompson and Co. Ltd.

${ }^{33}$ Goodall, Gas Export 1950.1960: A Summary of Oil and Gas Conservation Board Proceedings. Alberta Oil and Gas Conservation Board, January, 1961. The refusals reflected provincial doubt as to reserve adequacy.

34 Royal Commission on Energy, First Report, (1959) at 56, October 1958. The merger was precipitated largely by the Province of Alberta, as revealed in a letter of December 3, 1953 from the Provincial Premier to the Prime Minister.

The immediately urgent step is to bring about a satisfactory amalgamation of the interests and major proposals of the two applicants involved and my colleagues and I sincerely appreciate the assurance of your co-operation and active participation to that end. In transmitting to the applicants copies of the Board's report I have advised them that such an amalgamation is, in our opinion, essential in order to make possible the speedy completion of one sound over-all economically feasible project in which Canada's domestic interests will be served and augmented by the benefits of a desirable export market. 
and Commerce under its Minister, C. D. Howe, ${ }^{35}$ had been instrumental in securing the Alberta government's approval ${ }^{36}$ But as matters evolved public involvement was not to end here. At a very early stage TransCanada suffered financing problems ${ }^{37}$ which threatened to prove preemptory.

Faced with the prospect of the "all Canadian" pipeline not being built, an elaborate means of assisting the company was worked out between the Federal and Ontario governments. It was agreed that together they would finance a Crown corporation which would construct the Ontario section of the system. ${ }^{38}$ As this was the most difficult and expensive component, it would significantly ease the financial pressure on Trans-Canada. Once completed the Ontario segment of the line would be leased to the company at first, and over time ultimately bought outright. In the interim Trans-Canada would continue with the project as far as Winnipeg. Finally, in order not to deprive it of needed revenue while the Ontario section was under construction, export was to be allowed from Emerson to a subsidiary of Tennessee Gas Transmission, ${ }^{39}$ who would in turn supply gas to Ontario from U.S. sources through Niagara Falls. Thus the effect of this arrangement was to relieve TransCanada of first, the direct capital burdens associated with the Northern Ontario line and second, the costs of a delay of revenue as the pipe through the Pre-Cambrian Shield was completed. Ontario in turn was supplied with a volume of gas equivalent to that which it would otherwise have received from Alberta at a later stage via the Trans-Canada facility, and the financial risks ${ }^{40}$ of the venture were for the most part assumed by the Canadian public.

The risks, however, were slight. When the line was finally completed Trans-Canada was in the enviable position of servicing a ready-made eastern market: one which had been well-prepared via the U.S. gas imports. Once this happened the volume of exports via Emerson were reduced, and an additional minor export was permitted through the Niagara line, ${ }^{41}$ which, it will be recalled, carried the U.S. import originally.

From this example it can be readily seen that the role of exports from the point-of-view of the private interests at issue were, to say the very

ss Id. c. 4

${ }_{36}$ The Alberta permit, dated May 14, 1954, authorized the removal of 4.35 trillion cubic feet of gas at an initial rate of 540 million cubic feet daily (subsequently amended to 620 ) and 183 billion cubic feet in any consecutive 12 month period. 'The license was granted for a term of 27 years from the date of issuance.

37 The company was in fact unable to purchase the required supply of pipe. As it was to be a 34 inch diameter line it could only be obtained from the U.S. The supplier (the United States Steel Company) required the company to either establish a line of credit or an underwriting of its pipe line supply if orders were to be placed such that deliveries could be made during the 1956 construction season. Financing was a problem even for the initial western segment because of the company's "inability" to obtain sufficient gas purchase and sale contracts. A government loan was finally proposed that would cover up to 90 percent of the cost of western section (i.e., or not more than $\$ 80,000,000$ ).

${ }^{38}$ The Northern Ontario Pipe Line Crown Corporation was created on June 7, 1956. The Corporation was established to (a) construct the Northern Ontario section, and (b) make short-term loans to Trans-Canada on behalf of the Crown for the construction of the western section up to the limits referred to supra, $\mathrm{n}$. 37, at 5 percent from the respective dates upon which advances were made.

${ }^{9}$ Midwestern Gas Transmission Company. There was considerable controversy within the U.S. about this arrangement and initially the FPC would not give the proposal its sanction. A revised import arrangement involving Midwestern and the Michigan.Wisconsin Pipeline Company was ultimately approved however, and Trans-Canada did become the sole source of gas supply for the northern portion of Midwestern's service network which represented something of a watershed in FPC import-thinking. Activity commenced in August of 1960 .

40 The Northern Ontario route, because it had to be laid over solid granite, was by far the most costly section. Construction had also to proceed in face of extreme climatic conditions.

"See Miller supra, n. 22 at 111-114, for a detailed discussion of the midwestern export component of the plan. 
least, crucial. ${ }^{42}$ Likewise was the intervention of the Federal and Provincial Governments. ${ }^{43}$ Without both governments the economic burdens of formidable geographical barriers, concomitant financing difficulties, and market uncertainties would have led to a lengthy postponement of the project.

\section{The Export Controversy and the Royal Commission on Energy}

The "great pipeline controversy" had a number of additional dimensions above and beyond the actual realization of an all-Canada facility; in particular, it was in large measure the cause of the collapse of the Federal Liberal Government in 1957.44 This in turn led to heightened awareness and debate about the status of the Canadian petroleum industry, and the need to propound a generic oil and gas export and development policy. ${ }^{45}$

On historical grounds alone Canada had much to fear from uncontrolled private petroleum development, and most especially as it involved export market service. The first Canada-U.S. natural gas export occurred as early as 1892 from Ontario fields to Buffalo. ${ }^{46}$ The producer, Provincial Natural Gas and Fuel Company, later expanded its market base to include Detroit and Toledo, Ohio ${ }^{47}$ in 1894. Over the first five years of service there was a rapid exhaustion of the Ontario gas fields. In 1899 Ontario Construction and Improvement Co. added twin lines from Essex County to Detroit. ${ }^{48}$ This market by itself absorbed fifty percent of the Essex production in its first year's operation. ${ }^{49}$ The consequential depletion proved to be so extensive that it shortly became impossible to satisfy even domestic demands. In response to this alarming situation, the basis of what was later to become the Exportation of Power and Fluids and Importation of Gas Act ${ }^{50}$ was passed, requiring, among other things, that all future energy exports and facilitating capital obtain the prior sanction of the Governor General in Council. ${ }^{51}$ Further, the licenses when granted were usually for the term of a year, ${ }^{52}$ and were subject to termination at will whenever domestic energy needs were endangered by export. ${ }^{53}$ The Cabinet in addition was given the jurisdiction to

12 It was crucial in that a pipeline probably could not have been built even as far east as Manitoba without the export orders. See supra, n. 37.

4 Via the Northern Ontario Pipe Line Corporation as respected the financial arrangements necessary to realize the project, and the inter-governmental consultation between the Federal Department of Trade and Commerce and the Premier of Alberta that resulted in the grant of removal permits to Trans-Canada.

44 The subsequent general election returned a Conservative Government under the leadership of Prime Minister John G. Diefenbaker.

45 The Royal Commission on Energy (or Borden Commission) was itself one symptom of this heightened public awareness.

46 The first line extended from Welland gas wells to Buffalo, New York, via Lake Ontario and was laid in 1890 . An eight inch line was put down in 1894 from Essex County wells to the border near Windsor and through to Toledo, Ohio.

47 See Miller, supra, n. 22 at 76. Canadian well operator revenues rose from $\$ 150,000$ in 1892 to $\$ 440,904$ in 1899 but production over the same period was in sharp decline.

4. Id. at 75-76:

In April, 1900, an Order in Council of the Ontario Government revoked the eight-months-old authorization for the dual crossing of the Detroit River, because of fears that the Essex County supplies would be exhausted. Exports to Toledo ceased in July of that year. Deliveries to Buffalo terminated by 1909 . Ontario continued to produce gas from local sources after exports ceased, but later gas finds in the province have never been adequate to meet provincial needs, much less provide a surplus for export 4 Id. (emphasis added)

so The Exportation of Power and Fluids and Importation of Gas Act, S.C. 1955, c. 14. The antecedent of this Act was the Electricity and Fluids Act, S.C. 1907, c. 7.

s1 Id. s. 3(1).

52 Id. $\mathrm{s} .5(\mathrm{c})$.

s3 Id. s. 5 . 
place heavy duties upon the exports permitted, ${ }^{54}$ and finally, the statute required that the actual export license be attached to any trans-border agreement, ${ }^{55}$ thus ensuring U.S. notice of the unreliability of Canadian supplies. As respected gas, the overall impact of these measures was to rule out U.S. exports for as long as half a century. ${ }^{56}$

Federal control of exports was further supplemented with the passing of the Pipe Lines Act in 1949.57 Under its terms a federal license was required to authorize the construction of all pipeline facilities, be they for domestic use or export service. ${ }^{58}$ In addition, the Board of Transport Commissioners ${ }^{59}$ retained supervisory control over the operating plans proposed with respect to such facilities. ${ }^{60}$ But, while the potential may have existed by virtue of this enactment for comprehensive regulatory management of petroleum energy development, there appears to have been little activity under it over the course of its ten year history. ${ }^{61}$

As noted, the great pipeline debate did, among other things, clearly point out the need for a more continuous and effective means of public control over private industrial participants. In the past, governmental policy had been either too sweeping to be of much effect, as shown by the general terms of the Exportation of Power and Fluids and Importation of Gas Act, ${ }^{62}$ or involved detail beyond the administrative capacity of anything but a separate regulatory agency as was shown by the past administration under the Pipe Lines Act.63 The fact that a petroleum. related controversy had been in large part responsible for the demise of one government was an additional and strong incentive to depoliticize the issue, and here again an on-going regulatory framework appeared to offer the most promise in this direction.

As a preliminary to such a development, and for its value as a means of defusing 64 the political excitement then attached to the petroleum issue, the Royal Commission on Energy ${ }^{65}$ (hereafter simply the Borden Commission or the Commission) was charged with the responsibility of assessing Canadian interests in respect of energy matters, and how they might best be accommodated in the future. ${ }^{66}$

The Borden Commission was under a rather heavy onus. As respected the question of U.S. gas sales, the Canadian best interests had long since

54 Id. s. 4.

ss Id.

56 Miller, supra, n. 22 at 77.

37 The Pipe Lines Act, R.S.C. 1952, c. 211.

58 Id. s. 5.

59 Under Part II of the Act the Board of Transport Commissioners could regulate the tolls, traffic, and tariffe of all oil pipeline companies subject to the jurisdiction of Canada.

${ }^{60}$ Supra, n. 57, s. 6.

61 In particular the Board at no time exercised control over transportation rates charged by pipeline companies.

62 Supra, n. 50. It was too sweeping in the sense that it imported too many restrictions. The short-term nature of exports and the requirement that American purchasers be visibly put on notice of the unreliability of Canadian gas supplies (via attachment of the export permit) perhaps unduly limited Canadian exports. Such controls may have been appropriate vis.a-vis the Essex County demand and reserve picture in the early 1900's, and may well become appropriate with respect to the Western Canadian Sedimentary Basin within the Basin within the decade. But as a blanket rule, particularly as respects areas with discovery within the Basin within the decade. But as a blanket rule, particularly as respects areas with discovery
potential, so rigid a system of controls whose principal impact can only be to stifle export market service and depreciate the reliability and therefore value of any Canadian gas actually exported, has the concomitant effect of reducing development of otherwise productive reserve areas which could be of future national value.

63 See generally supra, n. 34, c. 2.

64 See Globe and Mail Magazine Section, February 25, 1972.

6s The Royal Commission on Energy consisted of six Commissioners, Chairman Henry Borden, C.M.G.Q.C., J. Louis Levesque, G. E. Britnell, R. D. Howland, Leon J. Ladner, Q.C., R. Macdonald Hardy.

${ }_{66}^{66}$ For the specific terms of reference of the Commission, see Order in Council P.C. 1957-1386, Appendix B, III. 
ceased being the simple "export" or "do not export" question that lay at issue in the Essex County crisis fifty years previously. ${ }^{67} \mathrm{By}$ the 1950 's a large part of the western economy was inextricably tied to the wellbeing of the industry. ${ }^{68}$ Markets, either in the United States or in Canada, were of vital concern. These in turn were in substantial measure contingent upon the subsistence of favourable price conditions, ${ }^{69}$ and because of the potential for significant scale-economies in petroleum production, ${ }^{70}$ prices, volume, and stable markets assumed a circularity ${ }^{71}$ that made an easy resolution of the national interest a rather unlikely prospect. Other factors served to convolute the question still further. For example, the correlation ${ }^{72}$ between exploration and development of reserve areas, and the level of profit earnings within the industry was of obvious importance: particularly in Canada's case where there still existed substantial sedimentary areas whose hydrocarbon potential remained for the most part unassessed. ${ }^{73}$ This fact in turn forced the hands of the Commissioners vis-à-vis possible recommendations for future Canadian policy to make basically one of two choices; namely, they were obliged to assess, as a matter of judgment, whether Canada was "rich" or "poor" in terms of its economically-accessible petroleum resources (and most especially natural gas) in advance of much in the way of confirming physical evidence. ${ }^{74}$ Having in view the extensive sedimentary basin areas in the country, ${ }^{75}$ the Borden Commission assumed scarcity not to be a problem. ${ }^{76}$ This conclusion for its own part made it possible to encourage an export-oriented policy which would have the effect of expanding the producers' market, potentially optimizing the

${ }^{67}$ See Miller, supra, n. 22.

${ }^{6 y}$ In 1955 more than $\$ 900$ million was invested in exploration and development, production, processing, transportation, distribution and marketing. $C f$. Davis, supra, n. 7 at 325 .

${ }^{69}$ Canadian gas, assuming all other factors equal, had to be at least competitive with U.S. indigenous supplies In fact, as will be considered at some length below, over the early 1950's the price of Canadian exports had to be substantially below that of domestic American supplies in order to offset the FPC's misgivings about developing too great a reliance upon external energy supplies.

${ }^{70}$ The deriving of scale advantages of course was itself dependent upon ultimate sale prices at the border and an apportionment of capital costs between the domestic and export markets that would permit delivery of natural gas to Canadian consumers at a price lower than that which would have been true if a smaller facility had been realized.

${ }^{7} E . g$., volume of throughput would be a main determinant of the efficiency with which the pipeline could be utilized and thus the main factor influencing the derivation of the optimum economies-of-scale that were available. In this connection a price discount might well be traded off as against a lower volume of throughput. But too great a price discount could ultimately nullify the benefits of a larger-than-necessary (i.e., for the domestic market alone) facility. Consistent markets and stable volumes also contributed to stable governmental royalties and stable industry earnings. And the latter particularly was significant vis.à-vis the ability of the industry to attract risk capital. Here again was another incentive to accept lower prices in return for the promise of stable revenues. And finally the extent of market growth was itself to a large extent contingent upon prices, and for a period might warrant a less-than-optimal sales price structure in the interest of obtaining both marketing economies and, enhanced long-term profit earnings (i.e., as rates were increased when the larger market had been established)

72 The NEB, FPC, and the industry on both sides of the border argue that this relationship is more than a mere correlation observable in an historical sense, and suggest instead that it is casual. On its logic it is a difficult proposition for it fails to account for the first entry into the industry and assumes away the presence of external risk capital that may be available to assist a particular venture notwithstanding industry earning trends in general. However, as a question of mere general trend the argument is perhaps less disputable.

${ }^{73}$ Most exploration until recently and all production to date has been confined to the Western Canadian Sedi mentary Basin. See Appendix B, I.

74 To the extent that the rate of discovery and development was contingent upon industry revenues and therefore markets, and to the degree that domestic markets alone would not provide the necessary encouragement to develop the industry in Canada, the judgment made by the Borden Commission in favour of servicing export markets was a defensible one.

75 See Appendix B, I.

${ }^{76}$ E.g., the Commission at one point supra, n. 34 at 3 noted that:

The evidence suggests that it is reasonable to anticipate, under favourable economic conditions, an ultimate discovery of some 300 trillion cubic feet of natural gas in the Western Canadian Sedimentary Basin.

This, when compared with the largest of today's assessments (i.e., the Canadian Petroleum Association) of 270 trillion cubic feet, reflects something of the optimism of the Borden Commission. Cf. Plowright, Talk Given to the Canadian Society of Wildlife and Fishing Biologists Symposium, 5 (1971). 
latent economies-of-scale, ${ }^{77}$ and reducing (theoretically) the prices of petroleum products in the Canadian market. ${ }^{78}$ It would in addition increase the rate of exploration and discovery, ${ }^{79}$ and hopefully prove the general assumption made by the Commission about long term petroleum supplies to be a self-fulfilling prophesy.

A related factor which made the work of the Commission difficult was the assessment of the potentials for integrating the Eastern Canadian markets with Western supplies. The Trans-Canada Pipeline case had clearly demonstrated the usefulness of an export component as a means of first, reducing the risk factor for the private enterprises involved, and second, as a means of ensuring that facilities were used at full capacity (and thus at maximum efficiency vis-ă-vis operation costs per unit of throughput). But it was also apparent that a number of contingencies were vital to such combined-purpose schemes. U.S. market reliance and long-term planning interests made export contracts necessarily of a rather long-term nature. ${ }^{81}$ On the other hand, the Eastern markets could be expected to experience significant growth in the medium-to-long terms. ${ }^{82}$ Thus a certain amount of excess capacity was a desirable end. The issue of course turned upon who should pay for this excess: ${ }^{83}$ the Canadian or U.S. consumer, or both? Pricing of exports was for this reason of vital interest ${ }^{84}$ and presumably would make up a substantial portion of the workload of any regulatory agency. Indeed the Borden Commission recommended in this regard that: 85

While, in the first instance, the terms and conditions of an export contract are matters of negotiation between the Canadian exporter and the purchaser of natural gas, these terms and conditions should be examined when application is made for an export licence. The Government should be satisfied, not only with respect to the technical aspects of the contract but, also, with respect to its price provisions.

It is necessary to ensure that the minimum export price is fair and reasonable. Where sales to Canadian distributors, as well as export sales are involved, the price relationship, between Canadian sales and sales for export, should be such that Canadian sales will not contribute more than a fair and reasonable proportion of the total return to the shareholders on their investment in the gas transmission company.

The export contract should contain fair and reasonable provisions for price adjustments during the term of the contract, so that the exporter, and in turn the gas producers, will participate in any benefits accruing from general price increases occurring in the export markets.

In short, the Commissioners at an early stage managed to identify major problems in the areas of reserve assessment, projections of future Canadian demand, and export pricing that were necessarily basic to the

\footnotetext{
77 Supra, n. 34 at 9.

${ }^{78}$ As will be considered in more detail infra, a precondition for the realization of such economies is of course an integration between domestic and foreign market service.

${ }^{79}$ Supra, n. 34 at 8-9.

Bo Namely that they are extensive beyond the reasonably foreseeable domestic needs and thus exportable.

81 The Borden Commission assumed that export licenses would have to be for a term of at least twenty years or longer. Another factor of note here was the FPC's repeated complaint that there was too much of a potential security risk in relying upon exports (see Westcoast discussion infra) and here again long term licenses would in part serve to offset the U.S. objections.

82 Over ten to fifteen years.

83 It should be noted in this connection that "excess capacity" is not always easy to determine particularly when the export services a fluctuating energy market almost exclusively. In such a case there are only two choices available; namely the variation of throughput over time, or the construction of expensive storage facilities at the market distribution terminus. The question turns upon the most efficient means of accommodating the the market distribution terminus. The question turns upon the most efficient mean
market's needs, and often "excess capacity" will prove to be the more optimal choice.

s4 This, for the reasons noted will often be an extraordinarily complex calculus. See also supra, $\mathbf{n} .71$.

os Supro, n. 34 at 11-12.
} 
use of exports as a means of propelling Canadian industrial development. As will be seen below they were in this respect perhaps prophetic.

\section{THE NATIONAL ENERGY BOARD}

It was against this background, and the ultimate recommendations made by the Borden Commission that Parliament passed the National Energy Board Act in $1959 .^{86}$ The structure and general jurisdiction of the Board has been set out below.

\section{General Provisions}

The Board consists of seven members (a Chairman, Vice-Chairman, and five members-at-large) appointed by the Governor in Council for terms of seven years subject to good behaviour. The statute makes a number of demands of the members, ${ }^{87}$ the most important of which is its express prohibition of any interest in the petroleum industry..$^{88}$

The jurisdiction of the Board, so far as it concerns the on-going determination of the public interest, is extensive. Of particular note in this regard are the provisions of section 11(b) of the Act: 89

The Board has full and exclusive jurisdiction to inquire into, hear and determine any matter ... (b) where it appears to the Board that the circumstances may require the Board, in the public interest, to make any order or give any direction, leave or approval that by law it is authorized to make or give, or with respect to any matter, act or thing that by this Act or any such regulation, certificate, licence, permit, order or direction is prohibited, sanctioned or required to be done (emphasis added).

It is significant that by virtue of this provision the discretion as to when the Board should act has been left exclusively as an internal matter. This power is further enhanced by section 24 which confers upon the Board "all the powers of Commissioners under Part I of the Inquiries Act,"90 with respect to certain of its functions. ${ }^{91}$

While the legislation itself is divided into eight separate areas, ${ }^{92}$ the Board's specific jurisdiction can usefully be divided into three distinct categories: first, its advisory functions ${ }^{93}$ with respect to the Governor in Council, second, its specific controls over certificates of public convenience and necessity, traffic, tolls and tariffs, supervision of the

86 National Energy Board Act, S.C. 1959, c. 46.

87 Id. 8. 3. Members must be Canadian citizens, reside within 25 miles of the City of Ottawa, devote their whole time to the performance of Board duties, and be below 70 years of age.

8s Id. s. 3(5) provides in part:

A person is not eligible to be appointed or to continue as a member of the Board .... if as owner, shareholder, director, officer, partner or otherwise, he is engaged in the business of producing, selling, buying, transmitting, exporting, importing or otherwise dealing in hydrocarbons or power or if he holds any bond, debenture or other security of a company.

89 Supra, n. 86, Section 11(a) which has not been quoted above calls the Board to hear and determine violation by commission or omission that it believes may be occurring or to have occurred.

${ }^{80}$ Inquiries Act, R.S.C. 1970 , c. 154 . The powers of commissioners are set out in sections 4 and 5 . Section 4 provides that:

The commissioners have the power of summoning before them any witnesses, and of requiring them to give evidence on oath, or on solemn affirmation if they are persons entitled to affirm in civil matters, and orally or in writing, and to produce such documents and things as the commissioners deem requisite to the full investigation of the matters into which they are appointed to examine.

Section 5 gives the commissioners:

... the same power to enforce attendance of witnesses and to compel them to give evidence as is vested in any court of record in civil cases.

91 At issue here are the advisory functions which are detailed at greater length infra. It is important to note however that the terms of inquiry possible under the provisions relating to this portion of the Act are almost limitless, and potentially therefore the Part I powers of the Inquiries Act could be a very powerful and useful tool.

${ }^{02}$ Namely, National Energy Board, Advisory Functions, Certificates of Public Convenience and Necessity, Traffic, Tolls and Tariffs, Powers of Pipeline Companies, Exports and Imports, General and Transitional, and Repeal.

93 National Energy Board Act, supra, n. 86, s8. 22-24. 
private operations of pipeline companies, and exports and imports, ${ }^{94}$ and third, its general regulation-making authority. ${ }^{95}$ Each of these will be separately headed and considered, infra.

\section{Advisory Functions of the Board}

Section $22^{96}$ sets out the range of matters that the NEB is obliged to keep under continuous review. Included here are all matters "over which the Parliament of Canada has jurisdiction" 97 that relate to: ${ }^{98}$

(1) exploration

(2) production

(3) recovery

(4) manufacture

(5) processing

(6) transmission

(7) transportation

(8) distribution

(9) sale

(10) purchase

(11) exchange and disposal and;

(12) the status of sources of energy within and without Canada

This section further obliges the Board to: ${ }^{99}$

... report thereon from time to time to the Minister and shall recommend to the Minister such measures within the jurisdiction of the Parliament of Canada as it considers necessary or advisable in the public interest for the control, supervision, conservation, use, marketing and development of energy and sources of energy (emphasis added).

At a glance it can be seen that this provision places the Board under an enormous charge: one that embraces virtually every important aspect of all energy resource ${ }^{100}$ development in the country. This being the case, it is not altogether surprising that the NEB has a rather large degree of discretion in respect of its investigatory powers and procedures. In addition to its powers of inquiry under Title $\mathrm{I}^{101}$ of the Inquiries Act, ${ }^{102}$ the statute affords considerable flexibility in terms of the manner in which information vital to the business of the NEB can be best obtained. In particular Section $14^{103}$ allows the Board to inquire, hear, and determine

94 Id. Parts III, IV, V and VI, 8s. 25-87.

95 Id. Part VII, ss. 88-93.

96 Id. \&. 22(1):

The Board shall study and keep under review matters over which the Parliament of Canada has jurisdiction relating to the exploration for, production, recovery, manufacture, processing, transmission, transportation distribution, sale, purchase, exchange and disposal of energy and sources of energy within and outside of Canada, shall report thereon from time to time to the Minister and shall recommend to the Minister such measures within the jurisdiction of the Parliament of Canada as it considers necessary or advisable in the public interest for the control, supervision, conservation, use, marketing, and development of energy and sources of energy.

(2) The Board shall, at the request of the Minister, prepare studies and reports on any matter relating to energy or sources of energy, and shall recommend to the Minister the making of such arrangements as it considers desirable for co-operation with governmental or other agencies in or outside Canada in respect of matters relating to energy and sources of energy.

(3) In carrying out its duties and functions under this section, the Board shall, whenever appropriate utilize agencies of the Government of Canada to obtain technical, economic and statistical information and advice.

97 See infra Appendix A, concerning jurisdictional overlap.

98 National Energy Board Act, supra, n. 86, s. 22(7).

id.

${ }^{100}$ One notable exception, however, concerns that of nuclear fuel exploitation and development which is not under the Board's charge.

101 See supra, n. 90.

102 Id.

${ }^{103}$ Section 14(2) provides that:

The Board may of its own motion inquire into, hear and determine any matter or thing that under this Act it may inquire into, hear and determine. 
any matter within its power under the Act of its own motion, and in addition section 14(1) provides that: ${ }^{104}$

The Board or the Chairman may authorize any one of the members to report to the Board upon any question or matter arising in connection with the business of the Board, and the person so authorized has all the powers of the Board for the purpose of taking evidence or acquiring the necessary information for the purpose of such report, and upon such report being made to the Board, it may be adopted as the order of the Board or otherwise dealt with as the Board considers advisable.

To the extent that this provision facilitates maximum use of limited personnel, little in the way of criticism can be attached to this power. This is also true in relation to the Board's authority to conclusively determine whether a person is an "interested person" for the purposes of certification hearings, ${ }^{105}$ and for that matter its jurisdiction to hold public hearings in respect of any matter it considers requires them. ${ }^{106}$ However, such sweeping procedural power may do more than just accommodate the Board's assessment of the public interest for the purposes of fulfilling its advisory obligations. It may also, by an equal token, be employed to exclude testimonial inputs that can be germane to this same question. And whether such authority has in the past been used to expand or limit information coming before the Board is not immediately at issue. A far more telling point lies in the fact that the Board alone has the almost unfettered discretion to decide what evidence is apt to relate to public interest matters even before hearing it. Having in mind the range of its advisory duty, the dictates of common bureaucratic efficiency no doubt make this grant of authority prudent, but the concomitantly increased reliance of the public-at-large upon the perceptive abilities of the Board over its exercise cannot be over-emphasized. It is a trite but important point to remember just how extensive are the long-term public interests at stake in energy development. This public reliance is further accentuated by virtue of the technically complex nature of the issues that the Board must consider, and the fact that not all of its studies and reports are placed within the public domain. ${ }^{107}$

Another feature in respect of the NEB's advisory function deserves brief mention here, (although detailed considerations will be reserved to a later point in the discussion; ${ }^{108}$ ) namely, extra-territorial energy matters, and most especially Canadian-American cooperation ${ }^{109}$ in respect of energy problems. Of note here is section $22(2)$ which provides that: ${ }^{110}$

The Board shall, at the request of the Minister, prepare studies and reports on any matter relating to energy or sources of energy, and shall recommend to the Minister the making of such arrangements as it considers desirable for cooperation with govern-

104 National Energy Board Act, supra, n. 86. This power of delegation is further supplemented by section 13 which allows the Board to grant to one or more of its members, either jointly or severally, all or any of the powers, functions and duties of the Board under this Act, except the one under subsection (3) of section 36 , sections $37,38,39,42,44,46,47,49,82,84$, or 88 , or under Part IV.

105 Id. 8. 45, which provides in part that:

the decision of the Board as to whether a person is or is not an interested person for the purpose of this section is conclusive.

${ }_{106}$ Id. s. 20(3) provides that the Board may hold public hearings in respect of any matter not provided for specifically by s. 20(1) and s. 20(2) if it considers such hearings desirable.

107 In particular, advisory reports prepared by the Board pursuant to its s. 22 obligations may, per s. 23, be made public only with the approval of the Minister of Energy, Mines and Resources.

108 See infra discussion of the "Continental Energy Package".

${ }^{109}$ This cooperation has been formalized with the annual meeting of the Joint United States-Canadian Committee on Trade and Economic Affairs. At a less institutionalized level can be included the periodic inter-governmental meetings and negotiations which have recently occurred with respect to the "energy package". See infra n. 112.

110 National Energy Board Act, supra, n. 86. 
mental or other agencies in or outside Canada in respect of matters relating to energy and sources of energy.

Given the volume of exports of both natural gas and oil (and for that matter electric power) there can be little doubt as to the operative importance of this section. Specifically, without agreement ${ }^{111}$ from the U.S. Federal Power Commission on the one hand, and the National Energy Board on the other hand, an export of any kind would be impossible. This requirement of inter-agency cooperation at an international level, however, goes far beyond issues relating to merely individual export applications, to include more generic policy and planning ${ }^{112}$ aspects as well. ${ }^{113}$

\section{Specific Controls of the Board}

As noted above, the specific controls of the NEB embrace a number of distinct aspects of the industry. ${ }^{114}$ Section $26^{115}$ of the Act sets out the foundation of the Board's jurisdiction over pipeline development in Canada. It provides that no company ${ }^{116}$ shall operate a pipeline unless a valid certificate has been issued, ${ }^{117}$ or leave has been given under the Act. This provision is complemented by section $27^{118}$ which further prohibits the initiation of a new facility without prior approval (via certification) first being obtained from the Board.

Certification procedure requires that the applicant company make rather extensive filings with the Board. ${ }^{119}$ Public notice ${ }^{120}$ of the application and the proposed route is required by the NEB, and it in turn has retained power to force diversions or relocations in routing both prior to, and subsequent to the construction of a line, ${ }^{121}$ if it is necessary to facilitate the construction of a work in the public interest; ${ }^{122}$ or to prevent or remove an interference with a drainage system. ${ }^{123}$ The power to alter part of a line has also been conferred upon the Board in the name of the public's safety. ${ }^{124}$ It can also condition a certificate with such terms as it considers desirable with respect to the purposes of the Act generally, ${ }_{125}$

111 The form of such agreement is by way of ratification of previously negotiated arrangements at the private level and not direct inter-agency negotiation. However, at an indirect level there may in fact occur such bargaining. See infra, for example, the Westcoast case and the respective refusals by the NEB and FPC to sanction the revised price agreements which were in excess of the original Sumas I price terms. Here the issue was clearly one of competing "public interests" in face of private accord among the two companies that were to execute the sale.

112 For example the FPC and NEB met over July of 1969 in Washington to consider the deficiency of U.S. natural gas discovery rates vis-à-vis the growth of U.S. demand. This was followed by a second meeting in September in Toronto after which the FPC issued its report warning of an impending U.S. natural gas shortage, and the NEB shortly received the innumerous export applications which led to the massive export approvals of August 1970.

113 See discussion infra.

114 Considerations relating to Board jurisdiction over the export and import of electrical energy have not been considered.

115 National Einergy Board Act, supra, n. 86 s. 26

116 Id. s. 26(2)

117 Id. 8. 26(1)(a).

118 Id. 8. 27. Such certification requires approval of the plan, and book of reference of the section of line at issue, and that these documents be deposited in the offices of the registrars of deeds for the district or counties through which the section of pipe is to pass.

119 Id. s. 29.

120 Id. 8. $28(2)$. Such notice is usually given via publication in newspapers.

121 Id. s. 37. Such a direction by the Board per this section need only be "upon such terms and conditions as it considers proper".

122 Id. s. $37(\mathrm{a})$.

${ }^{123}$ Id. s. 37(b)

124 Id. 8. 38.

125 Id. 8. $46(1)$. 
and specifically to promote restoration of the land over which construction is to take place, ${ }^{126}$ and to facilitate ${ }^{127}$ the conservation of topsoil.

The terms of reference of the Board in respect of how it should appraise a particular application are wide, although certification itself remains subject to Cabinet approval. The provision relevant here is section 44 which reads as follows: ${ }^{128}$

The Board may, subject to the approval of the Governor in Council, issue a certificate in respect of a pipe line or an international power line if the Board is satisfied that the line is and will be required by the present and future public convenience and necessity, and, in considering an application for a certificate, the Board shall take into account all such matters as to it appear to be relevant, and without limiting the generality of the foregoing, the Board may have regard to the following:

(a) the availability of oil or gas to the pipe line or power to the international powerline, as the case may be;

(b) the existence of markets, actual or potential;

(c) the economic feasibility of the pipe line or international power line;

(d) the financial responsibility and financial structure of the applicant, the methods of financing the line and the extent to which Canadians will have an opportunity of participating in the financing, engineering and construction of the line; and

(e) any public interest that in the Board's opinion may be affected by the granting or the refusing of the application (emphasis added).

The Board is obliged under section $45^{129}$ to hear and consider the objections of any interested person, however the Board happens to define that status. ${ }^{130}$ While it is unimaginable that this power would be used to exclude interventions by other petroleum companies, or landholders, or municipal representatives, the standing of public interest spokesmen, environmental groups, and others without a direct pecuniary interest at stake in the proceedings, may be on less sure ground. ${ }^{131}$

The NEB has more or less full authority to make orders "with respect to all matters relating to traffic, tolls or tariffs."132 Indeed a company cannot deviate from tolls specified in a filed tariff, ${ }^{133}$ and all such charges arrived at by contract must be so filed. ${ }^{134}$ The Act further appears to afford the potential for on-going price regulation by the Board. In this connection section 52 provides that: ${ }^{135}$

All tolls shall be just and reasonable, and shall always, under substantially similar circumstances and conditions with respect to all traffic of the same description carried over the same route, be charged equally to all persons at the same rate (emphasis added).

The Act contains specific provisions aimed at preventing "unjust dis-

${ }_{126}$ Id. s. $46(2)(\mathrm{a})$.

${ }^{127} I d . \mathrm{s.} 46(2)(\mathrm{b})$.

${ }^{128}$ Id. s. 44

${ }^{129} \mathrm{Id}$. s. 45

${ }^{130}$ See supra, n. 105.

131 So-called "public interest representation" has been a comparatively recent experience for the Board. The University of Toronto's Pollution Probe and the Ontario Waffle Group in the New Democratic Party appeared as intervenors during the most recent gas export applications before the Board (i.e., In the Matter of the Applications under the National Energy Board Act of Alberta and Southern Gas Co. Lid., Alberta Natural Gas Company. Canadian-Montana Pipe Line Company, Consolidated Natural Gas Ltd., Consolidated Pipe Lines Company, Trans-Canada Pipe Lines Limited, National Energy Board Reasons for Decision, November 1971). While the Board at no time disputed the standing of such groups only one of the applicants (Alberta and Southern) bothered to forward its submission prior to the hearing (i.e., at least in the case of Pollution Probe), and in general the participation of extra-industry spokesmen was looked upon more as a diversion from the usua business of the hearings than properly part of them.

132 National Energy Board Act, supra, n. 86, s. 50.

133 Id. 8. $57(1)$.

134 Id. 8. 51(2)

${ }^{135}$ Id. s. 52 . 
crimination" in tolls, ${ }^{136}$ service, or facilities against any person or locality. "Person" or "locality" probably does not encompass extra-nationals or areas outside of Canada although some contrary argument exists. ${ }^{137}$

The Board's ability to involve itself in industry price negotiations is complemented by section $58(3)^{138}$ which allows it to "prescribe the terms and conditions under which hydrocarbons may be transmitted by a company." Further, sections $53^{139}$ and $54^{140}$ permit the Board to disallow or suspend any tariff or portion thereof with which it takes issue.

The Board also has a measure of affirmative power over the creation and day-to-day operation of oil and gas transmission facilities. In particular, if the Board considers it in the public interest, it can force the addition to or improvement of facilities so as to connect with other facilities, or so as to include new service areas so long as no "undue burden" is placed upon the concerned company or companies thereby. ${ }^{141}$

Once again, in relation to the regulation of tolls, tariffs, and traffic, it is clear that the NEB has a sweeping authority. This is all the more significant for the imprecision inherent to such phrases as "just and reasonable" in section $52,{ }^{142}$ "unjust discrimination" in section $55,{ }^{143}$ and the "public interest" and "undue burden" references of section 5914 and 60.145 While it may be that greater statutory certainty with respect to these terms would not be consonant with the possibly greater need to facilitate rapid and effective regulatory intervention and involvement in industry affairs, the reliance placed upon the "good sense" of those acting in the name of the public should once more be noted.

${ }^{138}$ Section 61 concerns the situation where the pipeline owner is also owner of the throughput, in which case a toll is derived:

Where the gas transmitted by a company through its pipeline is property of the company, the differential between the cost to the company of the gas at the point where it enters its pipeline and the amount for which the gas is sold by the company, shall, for the purpose of this Part, be deemed to be a toll charged by the company to the purchaser for the transmission thereof.

137 At least one authority has argued that the scope of both FPC and NEB regulation, because of its inherently trans-national character (i.e., export sanctioning) has increasingly had to assume responsibility for the best interests of persons on both sides of the border. See Miller, supra, n. 22 at 201-205. In support of this thesis he notes the increasing reference by the FPC to "continental gas reserves" (which in turn is said to imply a con. tinental management perspective rather than a purely national one), the NEB's amity and comity principles which are said to guide its international dealings, and the growth of inter-governmental cooperation as shown by the formation of the United States-Canadian Committee on Trade and Economic Affairs. Miller also cites an FPC decision, 37 FPC at 1080-1081, which reads in part:

. we act in furtherance of the interests of United States consumers [but] where the proposal which best serves those interests would also be of particular benefit to consumers in Canada we welcome the opportunity to act in the interests of our Canadian neighbours as well.

It does not appear, to at least this reader, that this proposition lends much in the way of support to the argument that the "public" for the purposes of regulatory jurisdiction can be considered to include both national populations. It instead would seem to be a more reasonable view that extra-national benefits are entirely subject to the convenience of the regulatory agency which was in this case the FPC, and not the result of a new definition of its jurisdiction vis.d-vis the "public interest".

138 National Energy Board Act, supra, n. 86, s. 58(3).

${ }^{139}$ Id. $\mathrm{s}$. 53. The Board has under this provision the additional power to ". . . prescribe other tariffs in lieu of the tariff or portion thereof so disallowed."

${ }^{140} \mathrm{Id}$. 8. 54. This power of suspension can be exercised before or after the tariff takes effect.

141 Id. ss. 59(2) and 60.

142 Id. s. 52. In this regard the Borden Commission, supra, n. 34 at 11 stressed that it would be necessary to assess: ... field prices for gas in Canada and in the United States and of future price trends. It would be possible to determine that prices to producers are fair and reasonable and such as would allow the Canadian exporter a reasonable margin...

Another point worthy of passing mention here is that, were Miller's argument concerning the international character of "public" correct (supra, n. 137), s. 52 would prohibit price discrimination with respect to the export markets that aim at making export consumers assume a greater proportion of capital facility costs than domestic consumers.

${ }^{14.3}$ National Energy Board Act, supra, n. 86, s. 55 provides that: A company shall not make any unjust discrimination in tolls, service or facilities against any person or locality.

144 Id. 8. 59(2), which concerns Board orderings of facility extensions in the public interest.

145 Id. 8. 60, which concerns Board orderings of service extensions in the public interest. 
Part $\mathrm{V}^{146}$ of the Act details the general powers of pipeline companies, and is, save for one exception, not basic to the instant analysis except to the extent that the Board presumably has responsibility for ensuring that its provisions are complied with. The single exceptional provision is section $63: 147$

(1) A company shall not, without the leave of the Board, (a) sell, convey or lease to any person its pipe line, in whole or in part; (b) purchase or lease any pipe line from any person; (c) enter into an agreement for amalgamation with any other company; or

(d) abandon the operation of a pipe line.

(2) For the purposes of paragraph (b) of subsection (1), 'pipe line' includes a pipe line

as defined in section 2 or any other pipe line, and for the purposes of paragraph

(c) of that subsection, 'company' includes a company as defined in section 2 or any other company.

(3) Notwithstanding paragraph (a) of subsection (1), leave shall only be required where a company sells, conveys or leases such part or parts of its pipe line as are capable of being operated as a line for the transmission of gas or oil.

This provision relates significantly to section $44(\mathrm{~d})^{148}$ which, it will be remembered, provides for the Board's consideration of "the extent to which Canadians will have an opportunity of participating" in the development of pipe line facilities. Section 63 in turn prevents the undercutting of this earlier provision by preserving Board jurisdiction in respect of the transferring of ownership of already certified systems.

For the purposes of this analysis, perhaps the most critical aspect of Board jurisdiction is that contained in Part VI ${ }^{149}$ regarding the regulation of exports and imports. Pursuant to section 81 , licenses for exports and imports of gas are, save as varied by the regulations, required in all cases. ${ }^{150}$

Except as provided in the regulations no person shall export any gas or power or import any gas except under the authority of and in accordance with a licence issued under this Part.

As has been true elsewhere, the range of matters that the Board ${ }^{151}$ should consider particularly in relation to export applications, has been left largely to the discretion of that body. In this context section 83 is the controlling provision: ${ }^{152}$

Upon an application for a license the Board shall have regard to all considerations that appear to it to be relevant and, without limiting the generality of the foregoing, the Board shall satisfy itself that (a) the quantity of gas or power to be exported does not exceed the surplus remaining after due allowance has been made for the reasonably foreseeable requirements for use in Canada having regard, in the case of an application to export gas, to the trends in the discovery of gas in Canada; and (b) the price to be charged by an applicant for gas or power exported by him is just and reasonable in relation to the public interest (emphasis added).

With regard to the assessment of "reasonably foreseeable requirements," trends in discovery, and net future surpluses, the Board has evolved quite extensive and detailed procedures which will be the object of critical examination. ${ }^{153}$ At this juncture, however, attention should

\footnotetext{
146 Id. Part V, ss. 62.80.

147 Id. s. 63 .

14a See also s. 44

149 National Energy Board Act, supra, n. 86, s. 80A-87.

150 Id. s. 80A(a) defines gas as ". . natural gas or any fluid hydrocarbon or any fluid mixture of hydrocarbons other than oil."

151 Id. 8.81 .

152 Id. s. 83 .

${ }^{153}$ See Part V, infra
} 
be drawn once again to the great reliance placed upon the NEB to effectively cope with the large topics of uncertainty ${ }^{154}$ inherent in any large-scale export policy. While it is true that pursuant to the regulations the issuance of licenses for all exportation and importation of gas are subject to the prior approval of the Governor in Council,155 it is equally evident that the information supplied by the Board, ${ }^{156}$ and the recommendations made by it have a rather strong, if not decisive, role to play in Cabinet deliberations.

As is true of most questions of such complexity, there is a rather great potential for error. In this regard the Act contains two important safeguards. First, under section $82(3): 157$

Every license is subject to the condition that the provisions of this Act and the regulations in force at the date of issue thereof and as subsequently enacted, made or amended, as well as every order made under the authority of this Act will be complied with (emphasis added).

By virtue of this section the Board retains a large measure of ex post facto jurisdiction owing to the retroactive effect of regulations ${ }^{158}$ made pursuant to the Act, and although there are interesting construction problems, ${ }^{159}$ including quite possibly the retroactive impact of its own orders, the power is possibly vital.

In addition section $84(1)$ provides that, subject to prior notice and a hearing: ${ }^{160}$

... the Board may by order, with the approval of the Governor in Council, revoke or suspend a license if any term or condition thereof has not been complied with or has been violated.

Section 84(1) represents the "teeth" to supplement section $82(3)$ in that it expressly details the procedure to be followed by the regulators in face of a violation of pre-or-post license "conditions".

The regulations passed under Part $\mathrm{VI}^{161}$ require detailed information submissions by applicants in respect of export ${ }^{162}$ and import licenses. There is also provision for the extension of Part VI to oil as well as gas and power, ${ }^{163}$ which has in fact been acted upon ${ }^{164}$ (although the Governor in Council has the reserved jurisdiction to "exempt any class of oil or oil products or any area from the operation of all or any of the provisions of this Part", 165 by way of regulation).

154 Id.

155 National Energy Board Part VI Regulations SOR/59-1411 (1959) 93 Canada Gazette (Part II) 1044, November 11,1959 , regulation 8 at 1150 .

156 Any accords reached by the Canadian Section of the Joint United States-Canadian Committee on Trade and Economic Affairs presumably are crucially reliant upon the demand and supply estimates worked out by the Board. This is of course not surprising given the technical demands of the issues which first justified their removal from political process to a specialized on-going regulatory agency that could devote the time and expertise required.

157 National Energy Board Act, supra, n. 86, s. 83(2).

158 Such regulations can be made by both the Board per $8.88(1)$ with the approval of the Governor in Council, and by the Cabinet acting alone per 8.89 .

159 In particular, do the Orders have to reflect total compliance with later published regulations, and in the event of conflict does a new order have to issue, or is it automatically invalidated with respect to its offensive provisions?

160 National Energy Board Act, supra, n. 86. There is no litigation reported on this question which of itself may have something to say with respect to the degree of sympatico that prevails between regulators and regulated.

16. National Energy Board Act Part VI Regulations, supra, n. 155.

162 National Energy Board Rules of Practice and Procedure, Part I.

163 National Energy Board Act, supra, n. 86, 8. 87(1).

164 Extended to oil by proclamation dated May 7, 1970.

165 National Energy Board Act, supra, n. 86, s. 87(3). 


\section{The Regulation-Making Power of the Board}

Part VII ${ }^{166}$ of the Act concerns the regulation-making powers of the Board itself, and is of particular potential importance with respect to the control of both gas and oil exports. The relevant provision is section $88(1)(d): 167$

The Board may, with the approval of the Governor in Council, make regulations ...

(d) requiring companies and persons exporting gas or power or importing gas to furnish returns and information respecting capital, traffic revenues, expenses and such other information as may be required for the purposes of this Act.

Complementary power of inspection ${ }^{168}$ exists under the regulations which enables the NEB to insist upon complete information being given.

As a matter of practice, it should be noted also that section $88(1)(\mathrm{d})$ does not represent the de facto limit upon legislative changes or additions that result from the Board's initiative. The Governor in Council has, of course, the power to pass all types of regulations for "carrying the purposes and provisions" 169 of the Act into effect, as well as the unfettered power to make additions, amend, or repeal any portion of the Act. ${ }^{170}$ Such changes as have occurred to date are, perhaps not unexpectedly, the result of a close liaison with the Board.

To summarize, the National Energy Board enjoys enormously-broad statutory power over the Canadian petroleum industry's day-to-day, and long-term operations. While it is theoretically bound to the public interest, and is in fact subject to periodic Cabinet supervision, it has been given a great deal of control vis-à-vis the evolution of regulatory procedures best suited to fulfillment of its somewhat imprecise mandate. As has been noted, the changing status of the Canadian industry, domestic Canadian energy needs, and Canadian public interests that result from rapidly changing conditions in a developing economy, and the evolution of competitive energy technologies, perhaps dictate the necessity for a high degree of regulatory discretion of this kind.

It should be noted, however, that there are a number of compensating risks which flow directly from such sweeping authority. The most important of these relate to the degree to which matters in the public interest are themselves subject to periodic review. Second is the question of how such changes in the public's best interest are best-assessed. For example should a wide range of public expression be sought, or should the matter be left as a concern more properly the subject of governmental policy-making, to be argued at the political level, or is the issue so inherently technical that it is best resolved between industry and regulatory "experts"? This question, among others, will be considered in the two subsequent sections of the paper which focus upon the approved export complexes, and the development of regulatory decision criteria respectively.

\section{THE MAJOR EXPORT COMPLEXES PRE-1971}

With respect to natural gas exports, there are four major systems at issue, along with several lesser operations which do not deserve

\footnotetext{
166 Id. S8. 88-93.

167 Id. 8. 88(1).

${ }^{16 \nLeftarrow}$ National Energy Board Part VI Regulations, supra, n. 155 s. 14.

169 National Energy Board Act, supra, n. 86, s. 89.

170 Pursuant to established principles of Parliamentary supremacy.
} 
great attention in the instant discussion. The former category includes Westcoast Transmission's export system in British Columbia, the Alberta and Southern, and Alberta Natural Gas Company operations in both of the westernmost provinces, Canadian-Montana's system in Alberta, and Trans-Canada Pipe Lines Limited and its Emerson Manitoba delivery facility. Each of these complexes has been separately considered below with regard to particular features of the export route, ultimate purchasers, corporate structures, and where relevant, points of controversy. This discussion is followed by a summary of the main generic issues that attach to the export question, and the extent to which the Board has (a) faced, and (b) accommodated them.

\section{Westcoast Transmission}

The Westcoast pipeline facility almost completely bisects the Province of British Columbia. ${ }^{171}$ Its most northerly terminus is but a few miles to the south of the B.C.-Yukon border. ${ }^{172}$ To the east it connects with the Alberta Gas Trunk Line Company pipe near the City of Fort St. John in the Peace River District; a geographic region which is shared between Alberta and British Columbia. Westcoast thus draws its gas supplies from producers in both provinces. The gas is then piped to the southwestern extremity of the country where it ultimately flows across the international frontier near the Canadian Town of Huntington. At the border the gas is carried to various points in the U.S. Pacific Northwest by El Paso Natural Gas Company, and through the States of Oregon, Idaho, Wyoming, Utah, Colorado, New Mexico, and Arizona, eventually to reach San Francisco ${ }^{173}$ via the facilities of Pacific Gas and Electric Company.

The Huntington export began amid considerable controversy on both sides of the border, some of which persists ${ }^{174}$ to this date. In 1950 Westcoast initially proposed to the U.S. Federal Power Commission that it service the gas needs of Western Washington and Oregon via a 400 mile system in the U.S., which would be built and operated by a wholly-owned subsidiary of the Canadian company. A U.S. company, Pacific Northwest Pipeline Corporation, thereafter argued that it should be permitted to serve this area via a 1,400 mile system which would draw from gas reserves in the San Juan Basin of New Mexico and California. The issue was set down for hearing, and in June of 1954 the FPC rejected the Canadian plan. ${ }^{175}$ The decision to a large part reflected the Commission's anxiety over the build-up of too great a reliance upon supplies exogenous to the jurisdiction without "some inter-governmental agreement assuring the continued adequacy of . . . supply."176 At this time the FPC's feelings about foreign reliance were so firm that, ${ }^{177}$ even were Westcoast the sole applicant, it would nonetheless still have rejected the company's proposal, preferring instead to

\footnotetext{
171 See Appendix B, IV.

172 At present its northerly terminus is being extended from Fort Nelson to Beaver River which almost touches the B.C.-Yukon border.

173 See Appendix B, IV.

174 See infra. The controversy is both as between the Province and the Board over the prorationing of market areas vis-ä-vis B. C. procedures, and more generally as respects the sale price of the gas throughput. At its inception. there was also dispute from within the U.S. vis-à-vis reliance upon gas imports and in respect of competitive proposals for servicing the same market. This also has been elaborated in the main text.

17513 FPC 221 (1954).

176 Id.

${ }_{177}$ Id. Interestingly, the FPC could not find Westcoast's proposal to be economically feasible, saying that its route was too difficult, too distant, and involving too many indeterminate cost factors.
} 
reserve market service for a later scheme that would utilize indigenous gas sources rather than Canadian exports. ${ }^{178}$

The issue, however, did not rest here. Westcoast appealed from the FPC decision to the U.S. courts, as it was entitled to do under the U.S. Natural Gas Act. ${ }^{179}$ The resultant uncertainty of possible future court action effectively pre-empted the Pacific Northwest plan, for it made it impossible for the company to finance the required $\$ 160$ million in the interim. ${ }^{180}$

In order to resolve the confusion, a compromise was reached between the two companies. Pacific Northwest agreed to purchase gas from the Canadian system near Huntington under a twenty year term. ${ }^{181}$ The price settled upon was the average gas price charged by distributors in the cities of Portland, Seattle, and Vancouver, less the cost of transmitting the gas to each of the two former cities from the Canadian border. ${ }^{182}$ The necessary Canadian and U.S. approval was secured and service commenced in October of 1957. But it was not long before the agreement came under fire in Canada, most especially as it concerned the agreed contractual price. The Borden Commission for example questioned whether: ${ }^{183}$

... the agreement with Pacific Northwest is so onerous that, in effect, the Canadian consumer buying from B.C. Electric and Inland is subsidizing the delivery of gas to Pacific Northwest.

To assist in its appraisal, the services of Stone and Webster Canada Limited were obtained by the Commission. They subsequently discovered, on the basis of information filed before the Commission, that the company's operating profits "were coming solely from the Canadian consumer and no profit was being made by Westcoast in carrying out the terms of its contract with Pacific Northwest."184 The Commission also objected to the fact that company shareholders could only look to Canadian gas consumers for profit earnings. It was a situation that left much to be desired, particularly for the reason that Pacific Northwest had itself become a 25 percent shareholder in the Canadian company. ${ }^{185}$ In this connection the Report somewhat euphemistically observed that: ${ }^{186}$

It would not be in the public interest of Canada for [Pacific Northwest] not only to benefit from a contract negotiated with Westcoast at a time when the bargaining powers of each company were not equal, but also to benefit, as a shareholder, from prices charged to Canadian consumers of gas in order to make the project a profitable one.

178 On the Canadian side there was no expression of alarm about the fact that, were the export market to be approved, U.S. reliance upon Canadian gas would also increase, posing later problems if domestic needs grew to the point that they became competitive.

179 Natural Gas Act of 1938.

180 Miller, supra, n. 22 at 103.

Is! Id.

182 The Borden Commission First Report, supra, n. 21 at 22, contains the following passage:

Senior executive officers of Westcoast when they first appeared before the Commission explained that the price per mcf to be paid for gas by Pacific Northwest had been determined by reference to the laid-down price of Texas gas in San Francisco. This price was 34 cents per mef and as it was estimated it would cost 12 cents to transport the gas from the Canadian border to San Francisco, the price of 22 cents was thereby determined. These officers admitted that none of the gas sold by Westcoast in fact went to San Francisco and admitted that there would be some additional cost to be added to the 34 cents to move Texas gas to the Pacific Northwest area.

is3 Id. at 23

184 Id.

185 Id. at 17. Pacific Northwest had originally "demanded" 50 percent of Westcoast's equity as part of the consideration for entering into a gas purchase contract with the Canadian company.

186 Id. at 23. 
As the contract was both based upon a fixed price, ${ }^{187}$ and of a long term duration it was inevitable that, to the extent that the private agreement was allowed to continue to govern the situation, Canadian interests would remain compromised. Rising costs also made the agreement progressively less attractive for Westcoast, and the extent of the export volumes were held down below permitted levels by the Canadian company. The option provision given Pacific Northwest ${ }^{188}$ was also allowed to lapse in face of the Canadian company's "resolute insistence"189 on a higher price than that agreed. Several unsuccessful attempts at renegotiating the original contract were made. ${ }^{190}$ Early in 1966 the company and Pacific Northwest's successor, El Paso Natural Gas Company, finally agreed to terminate the 1954 contract and in its stead, substitute a new agreement for a larger volume of gas at a more favorable price. NEB approval was sought and received, but the $\mathrm{FPC}^{191}$ rejected the new arrangement because, first, it would increase costs to U.S. consumers then being served under the old agreement, and second, the prices charged by the Canadian company were "out of line" with respect to charges levied against the Canadian customers. ${ }^{192}$ Given these conditions the FPC said that its approval of the proposed increased volumes would not be issued until (as summarized by Miller): ${ }^{193}$

.. . the two companies renegotiate their contract so that the original 300,000 mcf per day under the 1954 contract and the additional 100,000 mcf per day would be purchased at a price not in excess of 29.5 cents per mcf at 95 percent load factor, without periodic escalation. ${ }^{194}$ This was tantamount to rejection of the proposal.

NEB reaction to the Commission's "in-line policy" was less than enthusiastic. ${ }^{195}$ On this basis the revised arrangement was rejected as being outside Canadian public interest. But despite its clear misgivings, the Board, in a bewildering move, nevertheless issued a temporary certificate to facilitate an export increase: 196

The furthest thing from the Board's mind in reaching this decision is to cause any hardship to users of gas in the Pacific Northwest. Any such effect would be regrettable on grounds of both international comity and of the Canadian interest in continuing to participate in the development of the Pacific Northwestern gas market.

Several factors came to Westcoast's aid in its efforts to obtain a higher price for the exported gas. First, Westcoast was owned 17 percent by El Paso, and to this degree the latter company was bound to indirectly share a portion of any hardship that would have befallen the

\footnotetext{
${ }^{167}$ In fact the price diminished after 1959, see Miller, supra, n. 22.

169 The company had an option to purchase an incremental 100,000 mcf per day at $22 \mathrm{c} / \mathrm{mcf}$ commencing in November of 1959 .

189 Miller, supra, n. 22 at 106.

190 One reason for this "resolute insistence" was the rising field prices that Westcoast was being confronted with. Initial prices had risen from $6 \mathrm{c} / \mathrm{mcf}$ in 1954 to $9.25 \mathrm{c} / \mathrm{mcf}$ in 1961 . By 1984 they were estimated to be at between 13.54 to $15.75 \% / \mathrm{mcf}$, at which point the losses to the Canadian company would reach staggering proportions.

191 August 10, 1967.

${ }_{193}$ The FPC estimated that the new price agreed upon would result in increased costs for U.S. consumers that were otherwise supplied under the old contract of between $\$ 45$ and $\$ 155$ million.

193 Miller, supra, n. 22 at 109.

194 The NEB would also have approved the arrangement if price provisions could be subjected to periodic negotiation in line of a fixed escalator provision.

195 "In line pricing" was of course inconsistent with the objectives of utilizing exports as a measure of creating a more favourable market for Canadians in terms of price structures. It also meant that the extent to which export revenues could be used to finance the line was in turn limited to the proportion of the export component vis-did-vis total throughput. The FPC stance was in addition nationally unpopular for its apparent extra-territorial reference in that Canadian acquiescence would seemingly have conferred a rather substantial measure of influence over domestic Canadian price structures.

196 National Energy Board, Reasons for Decision, In the Matter of the Application under the National Energy Board Act of Westcoast Transmission, (1967) at 8-28.
} 
Canadian company had not the price been revised. Second, one-half of Westcoast's gas supply was produced by Pacific Petroleum, Inc., which was owned 45 percent by Phillips Petroleum Company, who in turn held 27 percent of Westcoast's common stock. Thus all, from the field producers to the ultimate distributors, had a vested interest in saving the Canadian exporter. And finally a sizeable U.S. market had grown dependent upon the Canadian gas delivered by Westcoast. Thus in February of 1969 a new agreement was reached whereby the principals: ${ }^{197}$

. . negotiated a price approximately midway between the prices previously put forward by the companies but rejected by one or the other of the respective national agencies.

For the purposes of this analysis it is notable that the Canadian regulators still maintained doubts about the equity of the final price agreed upon but were once more prepared to give the benefit of that doubt in favour of an increased export. ${ }^{198}$ The NEB decision in this connection noted that quick settlement of the issue was a matter of some urgency, ${ }^{199}$ and that in the circumstances a "reasonable relationship of the contract price to the least cost alternative for the Pacific Northwest for energy from indigenous sources" 200 would be adjudged to be sufficient.

Exports through Huntington have increased since the 1969 accord, but the difficulties inherent to the financial dealings between the two companies still appear to plague the arrangement. Westcoast has, according to the Board, persistently exhibited "a unique flair for making complicated applications, and for complicating them further by amending them."201 But when these endless confusions are removed it is clear that over the history of dealings between Pacific Northwest and its later successor, El Paso on the one hand, and Westcoast on the other, the U.S. companies have in every case proved themselves to be far the superior bargainers. Nor has Westcoast learned from the experience. Even as late as 1970 the NEB complained that, just as was true of the 1954 agreement, the company again seemed prepared to blithely embark upon a new service commitment which would not allow it to adequately recover even its basic costs. ${ }^{202}$ But even the Board resorted to old habits, for, after noting that FPC approval had been obtained for the applications then before it, it again gave priority to U.S. energy needs rather than risk a time-consuming disruption of the agreement: ${ }^{203}$

In view of . . the urgency of meeting the immediate (1970-71) requirements of the Pacific Northwest for incremental gas supply, the Board is most reluctant to impose conditions .... which would require a reopening of the proceedings before the Federal Power Commission and, by lapse of time, wholly frustrate the construction of the facilities necessary to be installed in 1970 to deliver additional gas in the winter

\footnotetext{
187 Id. at 9.

188 Id. dispositions.

189 Id. at 9.

200 Id. at 10.

201 National Energy Board, Report to the Governor in Council. In the Matter of the Applications under the National Energy Board Act of Alberta and the Southern Gas Co. Ltd., Alberta Natural Gas Company, Canadian Montana Pipe Line Company, Consolidated Natural Gas Limited, Consolidated Pipe Lines Company, TransCanada Pipe Lines Limited, Westcoast Transmission Company Limited, (1970) at 10-56, 10-57, (hereafter referred to as National Energy Board Report to the Governor in Council, 1970)

202 Id. at $10-59,10-60$.

203 Id. at 10.60 .
} 
of 1970-71: it may indeed prove impracticable to complete these facilities in 1970 in the time remaining now.

\section{The Alberta and Southern Gas Company Ltd.}

Alberta and Southern is the Canadian subsidiary of California's Pacific Gas and Electric Company. ${ }^{204}$ The latter company has in addition, control over the Alberta Natural Gas Company which pipes the concerned gas over the B.C. portion of the Canadian side of the export route. It also owns Pacific Gas Transmission Company which transmits the gas from the Canadian-American border to the parent corporation's distribution facilities in the state of California. ${ }^{205}$

The export arrangement is roughly as follows:

(1) Alberta and Southern purchase the gas from fields in the province of Alberta;

(2) the gas is transhipped to the British Columbia and Alberta border by Alberta Gas Trunk Line Ltd., a Provincial Crown Corporation;

(3) from this point the gas is transmitted to the International Border near Kingsgate, B.C., by Alberta Natural Gas Company;

(4) whereupon delivery is assumed by Pacific Transmission. ${ }^{206}$

The system is a large one, having required an initial $\$ 340$ million capital investment, ${ }^{207}$ and utilizing 36 inch diameter pipe. Excess capacity was planned for from the onset. ${ }^{208}$

Pacific Gas and Electric Co., while it is the major customer serviced by its Canadian subsidiary, is not the only one. The additional volume is exported each year to Canadian-Montana Pipe Line facilities near the border, whereupon it is devoted to the consumptive needs of Montana Power Corporation. The details of this particular export arrangement will be discussed momentarily.

Neither of Alberta and Southern's export systems serve a Canadian market, being instead wholly export-oriented. This fact, in combination with the excess capacity feature of the Kingsgate system, has provoked a number of questions about the propriety of the arrangement from the point-of-view of Canadian interest. Not only are there no Canadian beneficiaries of the resultant scale economies, but: ${ }^{209}$

... [once] a large diameter pipe line is in place, the 'cheap expansibility' available in it gives its owners a very powerful lever in seeking supply contracts and authorizations to develop the system to optimum capacity.

As one company noted in 1970 Board proceedings, the leverage effect of excess capacity is accentuated considerably by the dictates of practical economics for: 210

... while there was no obligation connected with a provincial removal permit or a gas export license to provide continuing supply to an export market beyond the term

204 Id. at 1-1. Alberta and Southern is a company incorporated under the laws of Alberta, which would not seem to square with the direction of s. 25(1) of the Act which prohibits a person other than a company from the construction or operation of a pipeline, while s. 2(c) defines "company" as a person with authority under a Special Act to construct or operate pipelines, and s. 2(g) defines "Special Act" as being an authorization given a company by the force of Parliamentary enactment, or letters patent issued under $\mathrm{s} .5 \mathrm{~A}$ or $\mathrm{s} .5 \mathrm{D}$ of the Canada Corporation Act. Cf. National Energy Board Act, supra, n. 86.

205 Near San Francisco.

206 See Appendix B, IV.

207 Miller, supra, n. 22 at 120.

208 The Alberta and Southern pipe is thus Canada's largest export system.

${ }^{209}$ National Energy Board Report to the Governor in Council, 1970, supra, n. 201 at 10-42.

210 Id. at $4-27$. 
of the permit or license, facilities were constructed which had a physical life of 70 or 80 years, so it was logical to give priority to existing markets over new export markets.

Thus it can be seen that facilities such as Alberta and Southern's because they serve external consumers only, and because a depleting finite resource is at issue, enjoy a two-fold advantage over prospective new entrants: ${ }^{211}$

(1) on the one hand the mere existence of the pipe ensures a higher probability of obtaining a larger total share of the total exploitable reserve base than is true for a subsequently realized facility. The latter will very probably never be permitted to be of a size which would endanger a capital redundancy over the prospective life of the reserves in question;

(2) to the extent that the system has planned excess capacity, it is likely that its shares of present reserves will be allowed to increase in order to optimize capital utilization. ${ }^{212}$

There are a number of additional points of controversy concerning the Alberta and Southern export. As was true of the Westcoast case discussed above, there are once again pricing problems. The export contracts were drawn up on the basis of a "cost-of-service" formula worked out between subsidiary and parent companies. ${ }^{213}$ From the perspective of the exporting country this may well be of rather telling significance, for a cost-of-service formula does not aim at maximizing the revenues of the exporter. To the contrary it is clear that the prevailing market price and the price at this point of sale bear no necessary relationship. The case of Alberta and Southern has well illustrated this very point; for at one time Canadian natural gas was being shipped to California at a cost to the parent corporation of $26.4 \$ / \mathrm{mcf}$ as contrasted with the least-cost alternative in that market of $31.46 \mathrm{c} / \mathrm{mcf}^{214}$

Once more this is a problem area which the NEB has recognized to be a threat to the best interests of Canada: ${ }^{215}$

... there is in the present circumstances some gap, even though it cannot be readily quantified, between the cost of Canadian gas delivered under the present contractual arrangements and the cost of the lowest cost alternative energy from indigenous sources. This gap, or cost of cost of service, represents a subsidy by Canada to the United States consumers of the gas.

211 While the Board has acknowledged this advantage, and some of the problems that may be associated, and yet has not acted vis-à-vis the existing export complexes, it has in fact used it as a basis for refusing export proposals. An example of this can be found in the NEB's refusal of the applications and arguments in support of Consolidated Natural Gas in 1970. The Board noted that a 30 inch diameter line would have been more appropriate than the 36 inch line proposed by the company, and expressed some reservations about the consequences of excess capacity in terms of what would follow therefrom. The regulators noted, id. at 10-39, that:

... the installation of such a line would create considerable economic incentive, from Northern Natural's point of view, to fill it to optimum operating level as rapidly as possible.

212 This was succinctly expressed by the NEB, id. at 10-42, 10-43, as follows:

Where a choice has to be made between licensing additional quantities of gas for an existing project which has not hitherto been developed to optimum capacity, and licensing a new project of considerable merit the Board considers that it is consistent with the avoidance of misallocation of resources, which is one of the objectives underlying the regulation of quasi-monopolistic enterprises such as pipelines and railways, to make the choice in favour of the existing system, assuming of course that its proposal meets all relevant requirements (emphasis added).

213 This can be significant to the extent profit earnings may not be maximized for the subsidiary in order that the earnings of the parent can be enhanced. Whether this will or will not be so turns upon a complex array of variables, not least of which include varying rates of taxation as between jurisdictions, locus of corporate management and the degree of autonomy or lack thereof exercised by the subsidiary, capital and financing arrangements, and the capital markets to which the subsidiaries appeal, and the degree of sensitivity to parentsubsidiary dealings shown by the host country.

214 See Miller, supra, n. 22 at 123

215 National Energy Board Report to the Governor in Council, 1970, supra, n. 201 at 10-28. 
And yet the Board, in its most recent approval of an increase for Alberta and Southern's export line, argued that:216

\begin{abstract}
... it would be inconsistent with the amity and comity which has come to characterize relations between the United States and Canada in respect of trade in natural gas to withhold approval of export of the last 18 to 20 percent of the optimum throughput of the transmission system because of doubt that the price for this last increment will reflect its full opportunity cost in the California market.
\end{abstract}

On this rather tenuous basis the NEB went on to conclude that, in the context of the general relations between Canada and the United States respecting natural gas, "... the Board is satisfied that the price to be charged for the gas to be exported by Alberta and Southern is just and reasonable in relation to the public interest."218

\title{
3. The Canadian-Montana Pipe Line Company
}

The export system to be considered here crosses the international border between Alberta and Montana at two points: namely near the Towns of Whitlash and Robb. ${ }^{219}$ In the former case the export source was originally confined to the Pakowki Lake area in Southern Alberta. Reserves in this area are preponderately owned by Canadian-Montana Gas Company Ltd., and the company now purchases additional supplies from other producers in the same general region. Both CanadianMontana Gas Company Ltd., and the transporter, Canadian Montana Pipe Line Company are subsidiaries of the U.S. parent purchaser Montana Power Company.220

The export has a peculiar history. Montana Power's largest customer, Anaconda Copper Mining Company, consumed roughly 40 percent of the available peak capacity by the end of World War II when indigenous gas supplies within economic reach of the area were becoming increasingly inadequate. ${ }^{221}$ Imports from Alberta, while a logical source of additional gas, were hampered as the Provincial Government had not then assessed "reasonably foreseeable Provincial requirements" and, thus did not know what volumes if any could be safely exported.222

By the time both the U.S. and Canada were involved in the Korean War, Anaconda Copper Mining Company produced 23 percent of the United States' zinc, 8 percent of its copper, and 85 percent of its manganese; all of which came from the company's Montana operation. The strategic significance of ensured access to an increased supply of

216 It is rather clear that Alberta and Southern enjoy unique respect from the regulators which perhaps to some extent can account for the support which they have received in the past. In 1970 for example the Board, id. at 10-30, argued that:

The Alberta and Southern Project, in which Alberta and Southern is the exporting entity, has made a very significant contribution to the development of the natural gas industry in Western Canada, and in the course of building up its highly efficient and wholly reputable enterprise has hitherto paid more for Canadian gas than it need have paid for gas from United States sources.

What this statement does not make clear is whether the comparative cost of indigenous U.S. gas refers to wellhead or throughput cost. Nor does the Board's statement make any attempt at elaborating upon the company's "significant contributions" to the industry and the Western economy.

212 Id. at $10-30$.

218 Once again there was no analysis of what standards lie behind the notion of "just and reasonable" in relation to wholly-export oriented systems. See discussion infra, of Westcoast "just and reasonable" elaboration.

219 See Appendix B, IV.

220 Miller, supra, n. 22 at 95-96.

221 ld. at 96 .

222 This assessment was subsequently begun with the appointment of the Dinning Royal Commission which was established to study future provincial needs and the extent to which exports could be safely undertaken in light of such requirements. The Commission concluded that (a) there was an exportable surplus, but that (b) provincial consumers should be given priority, followed by (c) Canadian users who should be given preferred access to Alberta reserves over U.S. markets. 
natural gas, which had been employed by the company since 1931, was indisputable. Thus: ${ }^{223}$

... [t] $\mathrm{t}$ ] Canadian Department of Defense was asked to intercede with the province to ensure that the necessary supplemental gas supplies would be made available. A special law was enacted by the province authorizing the removal of up to 10 bcf per year at a daily rate of up to $40,000 \mathrm{mcf}$, from specified gas fields, for the exclusive benefit of Anaconda Copper Mining Company. A license to export was granted in 1951 by the Minister of Trade and Commerce under the Exportation of Power and Fluids and Importation of Gas Act, and the Board of Transport Commissioners authorized the necessary pipeline construction in Canada under the Pipelines Act.

This export has been enlarged considerably since 1951: so much that Montana Power's service market now includes several nearby towns in addition to Anaconda's growing needs. But the original Pakowki reserves were not themselves able to support the increased export from Canada. A second line entering the United States near Robb, Montana, supplied by Alberta and Southern, and transmitted to the international frontier by Alberta Gas Trunk Line Company Ltd.224 was created in $1960 .{ }^{225}$ By 1965, 73 percent of Montana Power's market needs were met by Canadian imports. This has been projected to rise to 96 percent by 1977.226 To date all purchase contracts have been on a cost-of-service formula, and again, with the exception of Alberta Gas Trunk, all dealings across the border have occurred between parent and subsidiary. Dissatisfaction with this system has, like the Westcoast case, had a long history. In 1957 one writer complained that: ${ }^{227}$

The situation with regard to exports into the State of Montana illustrates, in exag-
gerated fashion, the lack of awareness in this country both of the broader Canadian
interest in these matters and the intricities of parent-subsidiary trade spanning the
International Boundary. . . The Canadian subsidiary of Montana Power Company
has been permitted to charge its parent a price at the International Boundary com-
parable to that prevailing in other fields in Alberta. Canadian gas, priced in this way,
is being delivered at the Anaconda Smelter in Butte, Montana, at a cost to that
company between one-half and one-third of that which it would otherwise have
had to pay for energy in the form of coal or residual oil. Had the forces of supply
and demand been allowed free play, the return at the producing level would there-
fore have been higher and the profitability of the Canadian operations of the
Montana Power Company would have approximated much more closely that of
natural gas operations in similar situated fields in the United States. 4. Trans-Canada Pipe Lines

Extensive mention has already been made of the background of the Emerson export, and its importance vis- $a$-vis the creation of a TransCanadian pipe line system. With one exception, it is not necessary to probe further into this history. But it is of some relevance to examine more closely just how this export played so crucial a role. In this vein a single fact deserves underscoring: namely, that while the export made it possible for Trans-Canada to finance the western section of the facility, export revenues did not themselves finance the line. To under-

\footnotetext{
223 Miller, supra, n. 22 at 97

224 Alberta Gas Trunk is a "semi-public" Alberta corporation which throughputs gas on behalf of Alberta Southern, Trans-Canada, and Westcoast within the province. It is owned by producers, processors, utilities, and the exporters but is subject to provincial regulatory control.

225 Authorization for the second export through Robb, Montana was given in 1960. At the time the NEB warned Montana Power that the export itself could not be indefinite into the future and that the company look towards future needs from domestic U.S. sources. Notwithstanding this attitude exports have increased since.

226 Miller, supra, n. 22 at 99.

${ }^{227}$ Davis, supra, n. 7 at 166-67.
} 
stand this it should be noted that, at the time, the ability to finance rested upon the satisfaction of three preconditions: first, dedication of the reserves to the project; second, contracting of gas supplies; and, third, in the case of exports, the securing of the required governmental approval on both sides of the border. ${ }^{228}$ Trans-Canada prior to the export had only managed to satisfy two of these requirements. ${ }^{229}$ The company did not have the necessary market contracts, and without them was unable to obtain its pipe from the U.S. manufacturer. Market commitments were essential at this juncture, and an export component was a means of obtaining them. ${ }^{230}$ But on the revenue side, pricing provisions of the export contract made the scheme somewhat less attractive: 231

The net-back from the border price at Emerson, Manitoba, is well below that which could be recovered from sales to industry in Northern Ontario and Quebec. It is probably less than that which could be obtained by exporting Canadian gas westward from Southern Alberta directly into the United States Pacific Northwest.

Canadian participation in this market region from the standpoint of price considerations, has always been of rather dubious value. Although the market is large and growing, the midwest derives much of its gas needs through systems which have long since been written off, with the result being lower carrying charges than would otherwise be true. For a long period the gas delivered through these facilities was drawn from areas with lower field prices than is the case for Canadian gas from Alberta. This, in combination with the need to finance new delivery systems, and to cover great distances from source to market, all seem to reduce the revenue potential of exports into this region. ${ }^{232}$

The volume of exports through Emerson has nonetheless increased significantly since 1954 . In addition, less sizeable export systems to the U.S. eastern seaboard have since been added to Trans-Canada's service area. ${ }^{233}$ The original Northern Ontario route has proved to be an unqualified economic success despite the many problems that were encountered in its development. The Eastern Canadian market expanded sharply until it reached a point in the late sixties when it became evident that either existing lines would have to be looped, or a new line through a different route built to satisfy projected demands. TransCanada, however, remembering its past capital woes, viewed with a measure of trepidation the prospect of having to twin the Ontario pipe, and instead advocated the construction of an entirely new line to the south of the Great Lakes over American soil. Here problems of geography and climate were less formidable. In addition, new expanding export markets lay in the line's service range. A 989 mile, 36 inch diameter pipe, extending from Emerson, through the northern segments of Minnesota, Wisconsin, and Michigan through to Sarnia, Ontario, via the Straits of Mackinac, and thence southward via the western shore of Lake Huron to cross the border into Ontario a second time over the St. Clair River was put forward. It was proposed that a fifty-percent

228 Id. at 184 .

229 As has been noted above the company was beneficiary of a substantial measure of assistance vis-a-vis obtaining provincial removal permits, and of course had to obtain governmental approval in order to export at all. Without this external assistance the company in short would have been unable to meet any one of the tests.

230 Service agreements were less easy to obtain in the unprepared Eastern Canadian market.

231 Davis, supra, n. 7 at 173 .

232 Id.

233 See Appendix B, II. 
owned subsidiary company, Great Lakes Transmission, incorporated in the state of Delaware, undertake the project. The balance of its equity was taken up by the U.S. American Natural Gas Company.

NEB reaction initially was to oppose the plan, but after lengthy consultation with the Canadian company, it reversed its position. ${ }^{234}$ Considerably more opposition was encountered in the U.S., including such companies as Northern Natural Gas, Panhandle Eastern Pipe Line Company, and the Independent Petroleum Association of America. The latter argued that: 235

... mounting gas exports were against the best interests of the United States and a definite threat to the country's security because they rob American producers of money and incentive to find new reserves.

FPC sanction was obtained despite strong objections, and the project began in face of the subsequent judicial proceedings brought by Northern Natural against the U.S. regulators.

The ownership of Trans-Canada has, since its inception, been rather obscure, as has the issue of whether control derives from within Canada or the United States. ${ }^{236}$ It was argued at a very early stage that company management is heavily influenced by Americans because of its necessity to secure U.S. sales contracts. In this respect the major U.S. franchisers often assert an enormous power, and frequently have demanded a measure of control as the price for their cooperation. ${ }^{237}$ Tennessee Transmission, for example, owned Trans-Canada stock, and had a "major say" in the pricing of Canadian gas to its subsidiary, Mid-Western. ${ }^{238}$

In summary, it can be shown that the major Canadian exports exhibit a striking number of common traits. With respect to pricing provisions, a measure of doubt can be attached to each arrangement considered. In the cases of Alberta and Southern, and Canadian-Montana, the concern rests with the cost-of-service formula, while in the cases of Westcoast and Trans-Canada's Emerson export, the problem instead focuses upon the inadequacy of the particular price terms individuallynegotiated with the respective U.S. purchasers.

In all cases a high degree of corporate integration has been pointed to. While this may have no independent significance that can be identified without further study, it is at least a fact which the regulators should be alert to, vis-a-vis approval of privately-made export arrangements, and most particularly as respects pricing provisions. With respect

2:14 The reversal of the regulators was paralleled by the Federal Cabinet's. The first NEB export drew attention to the limitations it believed to be inherent to the project, but did not pass jud gment upon many of them believing them to be matters of policy unsuited to the proper exercise of its authority. In conclusion it recommended that the project be allowed to proceed. The Cabinet, however, presumably in light of the individual issues of policy noted by the Board, refused to follow the Board's recommendation, and rejected the plan on August $24,1966$. See Press Release, Office of the Prime Minister, August 25, 1966. The action was badly received by both the industry and the Provinces of Alberta, Manitoba, Ontario, and Quebec, all of which appealed to the Cabinet to reconsider its position. A series of conferences and joint meetings between provincial representatives and Canadian industry spokesmen, and senior Cabinet ministers followed, and the earlier decision was reversed on October 4, 1966 subject to the condition that at least 50 percent of the gas destined for Eastern Canada pass through the Northern Ontario facility. See Press Release, Office of the Prime Minister, October 4, 1966.

${ }^{233}$ Miller, supra, n. 22 at 117.

2.36 See Royal Commission, supra, n. 34 at $54-88$ and Davis, supra, n. 7 at 184. The company itself has shown a measure of sensitivity to this questioning as well and has recently engaged an advertising agency to draw attention to the fact that it has stockholders in each Canadian province by means of space purchases in major Canadian publications. None of these advertisements offer data on the proportional extent of Canadian ownership, however.

2.37 Id.

238 Id. at 186. 
to the past there is less doubt. It has been evident that because of the high degree of corporate integration, U.S. companies have been able to exert considerable influence over pricing principles that have been followed by Canadian subsidiary companies. ${ }^{239}$

Finally, brief mention has been made of the role of the NEB in respect of the difficulties that have grown out of the exports considered. It was argued that in each case unexpected priority was given to the status quo of prior agreements (re: cost-of-service provisions of the Alberta and Southern, and Canadian-Montana cases) and to the continued provision of Canadian supplies to the export markets in face of disputable aspects of the private bargains (re: Westcoast, CanadianMontana, Alberta and Southern). Attention will now be directed first, towards the more specific export criteria of the Board and how the above exports represent a compromise of Canada's best interests, followed by a discussion of the degree to which this may offer lessons for the future role of Canadian regulation.

\section{EXPORTS AND THE DEVELOPMENT OF PROCEDURAL CRITERIA}

The National Energy Board's public interest charge, as set out generally by section 11 of the Act, might be usefully subcategorized into the following major headings:

(a) the calculation of "exportable surpluses" vis-à-vis reasonably foreseeable domestic market requirements;

(b) the protection of the domestic gas market vis-à-vis price structures;

(c) the determination and application of "just and reasonable" export pricing;

(d) the promotion of mutually beneficial co-operative undertakings with trade partners, and most particularly the United States. ${ }^{240}$

Board procedure in respect of these questions is both technical and complex. An attempt has been made below to state; as simply as possible, the approaches employed by the NEB at both the theoretical and ideal levels. Regulatory perception of the difficulties associated with past export arrangements has been noted, as has the Board's willingness (or lack thereof) to take action that will help to offset some of these problems. Finally, in the interest of clarity and simplicity, obvious questions of overlap ${ }^{241}$ as between the categories have been ignored wherever possible.

239 Id.

240 In setting out such a list, it is perhaps also necessary to acknowledge a number of limitations that may be inherent to the exercise. To be precise, the success achieved by the Board in any one of the above areas envokes a methodological problem common to them all; namely as a question of procedure, what is the best means by which the Board can ferret out and analyze all of the information crucial to the assessment of future Canadian gas supplies, to take one example, or the data basic to understanding the rewards and hazards as a consequence of cooperative ventures between Canada and the United States, to take another. The degree to which an issue should be appraised as an "industry problem" or as "an energy supply problem" or as a "sovereignty question" will in many cases tailor the procedure appropriate to the Board's inquiries. In some cases it should perhaps be the duty of the regulators to inform and provoke public reaction in respect of matters that encounter generic issues of basic economic importance, such as might be true of a continental energy package. In other instances the nature of the problems being considered might be more expeditiously handled by means of closed and limited hearings on an informal basis. An illustration of this last case might concern technical aspects such as the degree to which butane can be substituted for natural gas, and therefore whether it should be included or excluded from the calculation of total gas reserves.

241 A second major limitation with respect to listing purportedly independently identifiable areas of the Board's public interest charge concerns a degree of overlap between each category. To illustrate a "just and reasonable price" will bear a relationship to the total quantity of "surplus" gas available for the export market. To this 


\section{The Calculation of "Exportable Surpluses"}

The Board's assessment of exportable reserves is contingent upon two major questions:

(1) the extent of present and future Canadian reserves; and

(2) the evaluation of reasonably foreseeable future domestic demand.

Under the Act it is only possible to export from surplus ${ }^{242}$ and, for this reason, the domestic reserve position must in all cases exceed projected requirements over the time period under consideration. Certainty in this connection is, however, at a premium, for the notions of needs, reserves, and surpluses are all time referential; that is to say none need necessarily factually exist as of the date of calculation. They are instead mere estimates or probabilities, and because this is the case, errors can be, and indeed frequently are, made. Thus the adequacy of the assumptions and formulae employed by the regulators to determine both sides of the demand and supply equation are especially critical matters. As the Borden Commission noted in this regard:243

[We have] found that there are several methods of assessing available sources of energy and accordingly ... [ [we find] that an important function of the National Energy Board will be to assist in establishing up-to-date uniform methods and standards for assessment of available and potential sources of energy. The Commission considers that the need for a Board which will maintain an up-to-date inventory of Canada's sources and potential sources of energy is self-evident if a sound national energy policy is to be developed (emphasis added).

But the calculus employed by the Board is both rigid and deceptively precise. Two statistics are involved in supply estimation; net reserves after deductions, and trends. Reserves fall into a number of subcategories and the terminology employed by the regulators is frequently misleading in result. For example, there are "established," "proven," "proved," "marketable," "estimated," "probable," "potential," and "possible" reserves, "reserves beyond economic reach" and "deferred reserves." Unfortunately these are rarely defined, and a clear comprehension of estimation procedure is thus obscured. To take one illustration, the term "established reserve" often is mistakenly taken to mean present, known, and certain gas volumes. In fact the expression as a "term of art" includes 100 percent of 'proved reserves' plus 50 percent of 'provable reserves'. ${ }^{244}$ Even proven (or proved) reserves are apt to be slightly misread for they too are only an estimate of the amount of

extent the accurate resolution of the question will be contingent upon the viability of the procedures that the Board employs in its estimation of future demand growth and the accuracy of its predictions with respect to increments to total reserves over the period to be considered. This same interdependence is also present in relation to long-term cooperative ventures with the United States, for their value or otherwise is tied in an obvious fashion to the proportion of total ultimate Canadian reserves that they may involve. And finally the value of preserved jurisdiction over energy sources and supply (discussed under point 2 ) is in one sense an "escape valve" that is wholly dependent upon the Board's degree of success vis. $\mathbb{d}$-vis the other areas. If its assessment of the Canadian energy picture is perfect, presumably its decision-making will also approach some measure of perfection, in which case its reserved power need never be exercised to alter an existing arrangement. While this sort of accuracy is of course demanding the impossible, it is nevertheless true that the relative im precision of Board appraisals of Canadian energy needs will be the main determinate of the necessity, and therefore value of the reserved power to amend, vary, or repeal an export commitment in the name of the public. But, having pointed to some of the disutilities involved in categorizing the principal public interest areas under Board jurisdiction, it is also appropriate to identify a solitary advantage which more than justifies the effort involved. In respect of energy matters the regulators exist in a world of uncertainty wherein confident precision often invites significant error. To the extent that it is possible to categorize and thereby isolate the principal areas of concern, it is also then possible to distill a critical appraisal of the Board's performance in terms of both its weaker and stronger areas.

${ }^{212}$ National Energy Board Act, supra, n. 86, s. 83(a).

249 Royal Commission, supra, n. 34 at 52.

244 Miller, supra, n. 22 at 184. 
gas in known deposits that can be recovered under current economic and operating conditions. A change in market conditions, or a shift in technology will induce corresponding changes, one way or the other, ${ }^{245}$ in the proven reserve estimates, which of themselves have little absolute significance.

The uncertainty factor inherent to the above definitions is revealed by the often sizeable variations in figures submitted to the Board whenever an application for export is being considered. For example, in 1970 the highest estimate of Canadian established reserves was a full 2.6 trillion cubic feet in excess of the lowest estimate. ${ }^{246}$ The Board, in attempting to appraise total marketable potential, and ultimate reserves, draws upon data from a range of sources. These include provincial governmental estimates, industry figures, and the results of field research by federal agencies ${ }^{247}$ including the Board itself. But the precise degree to which regulators, at both provincial and federal levels, depend upon industry-submitted data is not clear. There does not seem to exist a wholly-independent means of obtaining reserve information.

The calculation of established reserves is far from the last word in the determination of the supply side of the balance. Two estimates are deducted as against this figure: namely, reserves to be conserved for the purposes of conservation, and one-half of those reserves which remain "beyond economic reach" 248 over the operative time horizon.

A final, and less precise factor that bears an enormous weight on the reserve issue concerns the general question of judgment by the Board as to those areas which can properly be considered economically. exploitable, and those which cannot. The Board most recently considered this question in November of 1971 when it refused to include the finds in the Mackenzie Delta and elsewhere in the Arctic within its overall reserve calculus. ${ }^{249}$ To do otherwise, as a number of the hearing intervenors $^{250}$ advocated, would have greatly expanded the Canadian supply base (and therefore export potential), at least on paper. While these areas would still be technically considered "beyond economic reach," they would, under the Board's procedure, be given a 50 percent credit. There are thus two notions of "beyond economic reach" for the purposes of supply analysis:

(1) "beyond economic reach" as a term of art-refers to those reserves in established reserve areas which are inaccessible under present economic conditions; and

(2) "beyond economic reach" in a normal sense-refers to gas found in areas which are so distant that they will not be considered

245 Historically the changes in drilling and transmission technology have consistently meant that more natural gas reserves that were once uneconomic, became exploitable. However, it would be optimistic in the extreme to assume that future technological advances will in all cases increase the total exploitable reserve base as do groups such as the Canadian Petroleum Association. For example the development of an environmentally safe, low-cost breeder reactor would very probably make many natural gas finds less attractive, and some others unrenumerative compared to the thermonuclear alternative.

246 National Energy Board Report to the Governor in Council, 1970, supra, n. 201 at 4-1-12.

${ }^{247}$ For example the Geological Survey of Canada and the Department of Energy, Mines and Resources' other related offices.

${ }^{248}$ As will be explained infra the phrase "beyond economic reach," when employed by the Board is a term of art with a meaning quite distinct from that normally associated with it.

249 National Energy Board, Reasons for Decision. In the Matter of the Applications under the National Energy Board Act of Alberta and Southern Gas Co. Ltd., Alberta Natural Gas Company, Canadian-Montana Pipe Line Company, Consolidated Natural Gas Limited, Consolidated Pipe Lines Company, Trans-Canada Pipe Lines Limited, (1971) at 5-41, (hereafter referred to as National Energy Board, Reasons for Decision, 1971).

${ }^{250}$ In particular Dome Petroleum Limited, and Consolidated Natural Gas Limited. Id. section 3. 
'reserve areas' at all for the purposes of assessing Canadian supplies.

In short, Board procedures utilized to analyze Canadian present reserve status labour under a number of (often unescapable) weaknesses:

(1) reserve data derives from many sources, and in particular industrysupplied information appears to be crucial to the assessment process;

(2) reserves known to be beyond economic reach are arbitrarily added to the reserve sum by an amount equal to one-half their assessed volume, and not by a factor which is the result of a case-by-case analysis;

(3) an amount is deducted from reserves for purposes of conservation $^{251}$ (by a procedure which is unexplained);

(4) reserve data includes development areas which are commercially feasible in the view of the Board and does not encompass all sedimentary basins in Canada in which there have been gas finds.

The extrapolation from present to long term supplies is accomplished by the addition of trend gas. According to the Board: ${ }^{252}$

.. . the trend of discovery [can] be determined most reliably on the basis of the experience of increases in initial established reserves, from discoveries and appreciation, during the immediately preceding decade.

As was true in the case of the estimation of present reserves, the trend of discovery is considered in terms of accepted reserve areas only, and does not include, as of the time of writing, ${ }^{253}$ discoveries in northerly regions. Thus an estimate of annual increments to total reserves is made and applied over the export period for the purpose of establishing an approximation of the future supply conditions over the life of the export. The risk factor necessarily inherent to this procedure can be summarized as follows:

(1) to the extent that the trend gas estimate derives from historical rather than forward-looking analysis, it may under or overstate the true reserve status over the life of the export; and

(2) to the degree that the trend of discovery fails to describe the realized reserve increments, it may result in a net surplus or net deficit vis-à-vis Canadian needs; and

(3) while the risk of a surplus is not a problem, insofar as an export market will in all probability exist that can absorb it, a deficit has risks which are irreversible, absent a cancellation of the export arrangement before the above-mentioned deficit appreciates. ${ }^{254}$

251 The term "reserves deferred for conservation" is not defined in the Board reports and no indication is given as to whether the "conservation" is practiced to prevent unforeseen shortages in the Alberta market, or the Canadian market, or to prevent drilling in areas that would otherwise be despoiled (e.g., park and recreation areas), or whether the category is merely an extra "insurance" to protect against totally irreversible consequences from an error in past Board projections of demand and supply. In any case large volumes of gas are not placed within this category.

252 National Energy Board, Reasons for Decision, 1971, supra, n. 249 at 5-12.

253 March, 1972.

254 The free operation of the market, however, makes it rather unlikely that deficit conditions will actually occur (i.e., as supply falls relative to demand, prices will rise thus constraining use of natural gas). To the extent that this is so, Board estimates become something of a self-fulfilling prophesy, and the costs of regulatory conservatism vis-d-vis the protection of the Canadian consumer are obscured. The errors of the regulators in other words receive compensation in the market place and thus have a rather low profile. This of itself is one very strong incentive for the Board to stay clear of considering means of controlling energy prices and natural gas prices. 
The regulators have been reluctant to bind themselves to any predictions of ultimate Canadian gas reserves, and have been instead content with quoting the various assessments of the industry, and the Canadian Petroleum Association in particular. In 1970 the latter contended that potential natural gas reserves recoverable under conventional methods from the eight potential hydrocarbon areas of Canada totalled not less than 724.8 tcf. $^{255}$ This figure was based on the assumption that an average $6 \mathrm{mcf}$ of recoverable gas would be discovered in association with each barrel of potential crude oil reserve found. This last estimate in turn rested on the further assumption that the oil bearing potential of Canadian basins could be safely inferred from the total volume of sediments each contained. This method has been the subject of some controversy: 256

Volumetric calculations based on the amount of sedimentary rock present cannot be used to make any useful prediction of the amount of oil [or gas] ultimately recoverable from a basin not yet shown to be petroliferous. Canadians would not put much faith in a statement of their gold resources if it were prefaced by the stated assumption that the entire Precambrian shield contained half-an-ounce of gold per ton of rock. The phrase 'potential oil reserves' is misleading if it needs the unspoken preface 'assuming that every area of sedimentary rock in Canada is as petroliferous as Texas.' Yet many politicians and journalists, thousands of members of the public, and even some oilmen, are convinced that these staggering reserves are scientifically established as existing....

The capacity for optimism reflected by the Canadian.Petroleum Association's estimations is perhaps without modern-day equivalent. ${ }^{257}$ To assume productivity from all Canadian sedimentary areas, ${ }^{258}$ in face of the stark reality that but one-half of such areas in the world-at-large yet subjected to exploration produce, is perhaps a rather tenuous starting point from which to advocate development and export policy: ${ }^{259}$

The odds, if we consider them dispassionately and not as propagandists, are quite unacceptably long against any of these basins containing more than a fraction of the reserves prophesied for them. The odds against them all fulfilling the prophesies, between now and 1990, can be taken to be infinite. Canada will be extremely well endowed with oil [and gas] if the rest of this century sees her find an amount of new oil equal to the amount she has already found.

The mere discovery of oil or gas is of itself not a guarantee that production will necessarily follow. In some cases, particularly as respects the far north, reserve potential, even if established as being extensive, may prove to be of little real value: ${ }^{260}$

Because every phase of every operation, from transporting men and equipment into the field to transporting the oil out of it, would have to contend with treacherous open water, ice floes, Atlantic storms, permafrost, or muskeg, it would not be worth trying

255 National Energy Board Report to the Governor in Council, 1970, supra, n. 201 at 4-10.

256 North, Background Paper prepared in support of A General Intervention by Brian Kelly on behalf of Pollution Probe at the University of Toronto to the National Energy Board's Joint Hearing, (1971).

${ }^{257}$ In terms of established reserves, the magnitude of the variation between different approaches is relatively speaking diminutive when compared with the differences between ultimate reserve estimates. However, in an important sense the variances revealed in these figures are considerably more critical for established reserves are working figures employed by the Board in deciding whether or not to approve an application in respect of a long-term export contract. In short, an error here can have significant long-term implications vis-a-vis the availability of gas of immediately recoverable value to the Canadian market. As has been briefly noted above, here again is an area of some uncertainty for, not only do the estimates received by the Board during export hearings contain sizeable unexplained differentials, but the Board's means of appraising, comparatively, these figures is not known.

258 See Appendix B, I. The Canadian Petroleum Association does make this assumption for the purpose of estimating total ultimate reserve capacity.

259 Id.

$260 I d$. 
to tie that amount of oil into a market several thousand miles away unless virtually all of the oil was in a single gigantic field; a Prudhoe Bay in fact. Scattered smaller fields with the same total reserves, the situation typical of most producing basins, would be totally useless even if we could find them. Outside the Middle East, only four individual fields are known with reserves in excess of ten billion barrels:

We should therefore give very serious consideration to an utterly heretical conclusion: that the reserves we have any rational expectations of finding are not worth looking for.

The demand side of the equation also labours under many of the uncertainty factors described supra. Again data as to future Canadian requirements is drawn from multiple sources that include the industry, various public utilities, and provincial government departments, in addition to the Board's independent data compilations. Assessments are then summarized on a province-by-province basis over a period of four years. ${ }^{261}$ For the protection of "reasonably foreseeable" needs, the level of demand expected to prevail in four years' time is multiplied by a factor of twenty-five. Thus, if demands were assumed constant after four years' growth, the period of "reasonable foreseeability" would be twenty-five years. But to the extent that demands will in fact enlarge after the fourth year, the level of protection guaranteed by this formula is only a fraction of this period.

There are several difficulties that are inherent to this methodology, although once again some are very possibly unavoidable. But others significantly are not:

(1) the protection period (i.e., reasonably foreseeable domestic requirements) will vary depending upon the actual rates of change in demand experienced after the fourth year;

(2) the formulation critically relies upon the accuracy of the often incomplete information before the Board concerning anticipated changes in demand over the initial four years;

(3) the formulation does not take into consideration the degree to which Canadian natural gas demand in the future is price elastic or inelastic, and to this extent, the mere reservation of reserve gas, without regard to its relative price advantage, is unnecessarily crude. ${ }^{262}$

The past standard of performance vis-à-vis projecting long-term Canadian requirements has been poor. Beginning with the Borden Commission study, Canada has exhibited an alarming propensity to consistently understate the rate of expansion of domestic needs, with the unfortunate result that surpluses that have in the past been earmarked for export have been exaggerated. The graph reproduced below reveals something of this tendency, describing comparatively the projections computed and plotted as of the dates 1958,1969 , and 1971.

281 This procedure is the result of alterations made in 1971 when the Board noted, supra, $\mathrm{n}$. 249 at 4-11, that it had: .. endeavoured to evaluate the extent to which fuel substitution is possible in the industrial fuel market, particularly in British Columbia and Ontario. The Board's conclusions reflect the changed conditions in the energy market in Canada up to 1975 and are supported by the evidence presented to it during the hearing. But for the longer term extending beyond 1975, the possibility of substantial shifts in the demand, the supply and the price of various forms of energy makes a long-range forecast much less dependable at this time.

In the context of the Board's report of a short year before this is a startling admission. It would now seem that discovery trends are too low, and needs over a period of 4 years hard to assess because of the unusual rate of growth in the recent past. Without knowledge of trends and needs the surplus referred to by section 83(a) cannot be calculated, and yet in August of 1970 export commitments of 15 years and more were made by the Board notwithstanding doubts it must have held as to the changes then occurring in the domestic energy market, and which it openly acknowledged in its most recent report.

${ }^{262}$ See supra, n. 234. 
PROJECTION DISCREPANCIES-CANADIAN NATURAL GAS DEMANDS AS ILLUSTRATED BY A COMPARISON OF 1958, 1969 and 1971 ESTIMATES

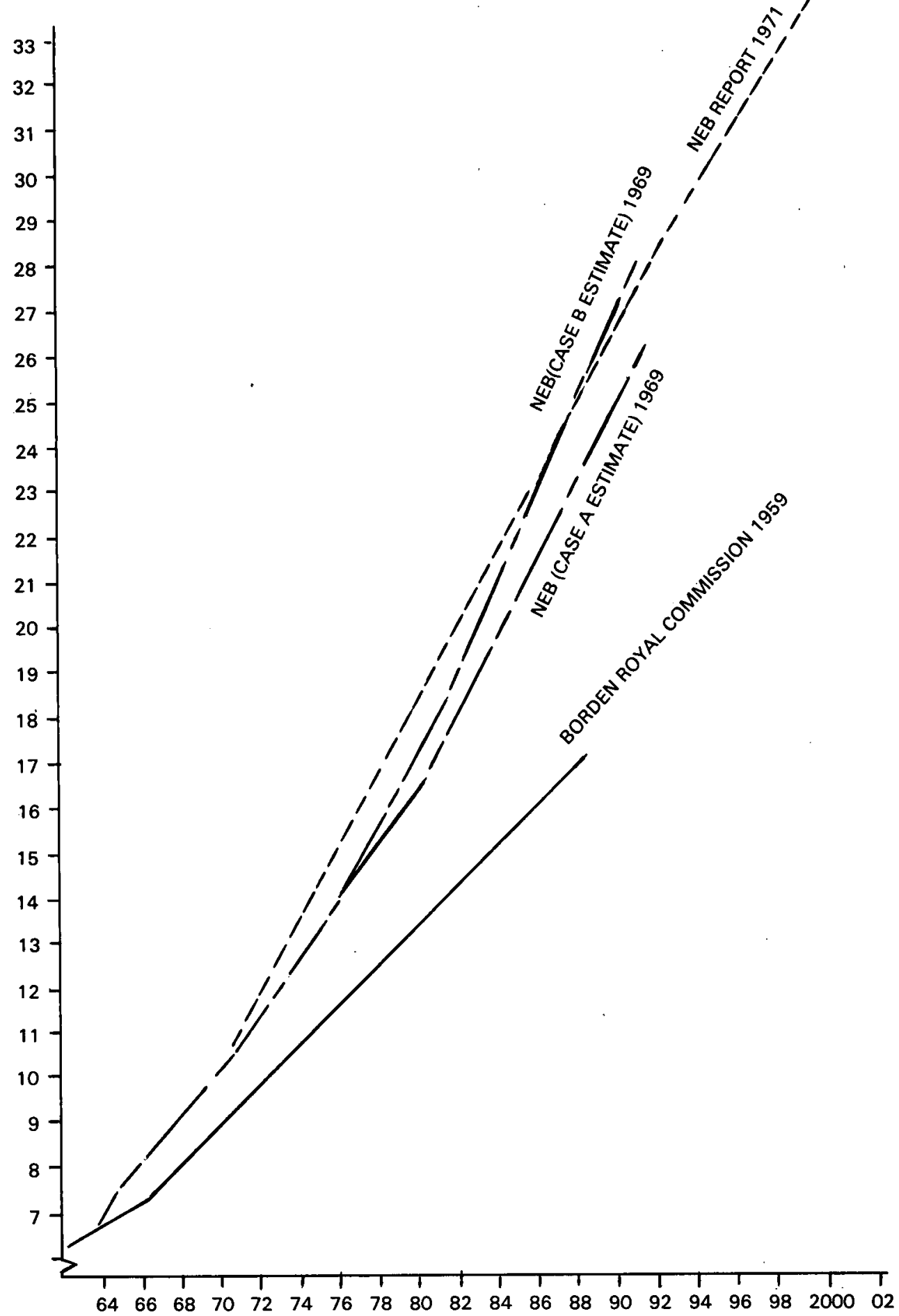


The saving grace that has prevented past deficit conditions from impairing the Canadian gas market has been the discovery and new production rates (i.e., trend gas discussed supra) enjoyed in the Canadian west until quite recently. So long as these continued to grow the risk assumed domestically from the Board overstating the extent of surplus gas available for export has been minimal. However as they decline, or if domestic demands begin to rise at a faster rate, then the reliance placed upon regulatory conservatism in respect of the export question increases considerably.

In the past the Board has in this regard calculated an average gross addition to established gas reserves of $3.5^{263}$ tcf per year to have proven true from 1959 to 1969 , based upon a least squares fitting of a straight line function. This was raised to 3.7 in $1971 .{ }^{264}$ But this improvement in discovery trends has been more than offset by the rate of increase in domestic demand for natural gas. ${ }^{265}$ In November of 1971, for example, the Board found that the necessary protection had grown by $4.3^{266}$ tcf since 31 December 1969. For this reason it became impossible for the NEB to approve the export applications then before it. Instead they were forced to acknowledge the prospect of a 1.1 tcf deficit in supplies (i.e., as against domestic needs and export commitments) per the projections as of 30 June 1971. In this context the regulators somewhat unhappily observed that: ${ }^{267}$

The importance of distilling out from the mass of conflicting opinions, observations and claims, a level of requirements, that could be called 'reasonably foreseeable' for Canada has weighed heavily on the Board. There is no doubt in the minds of the Board that gas which was [in the past] declared surplus to Canada's needs and was licensed to be exported from Canada pursuant to earlier proceedings and approval by the Governor in Council, has played an important part in providing cash flows and encouragement for the producing companies to continue to explore for more gas in Canada.

On close reading this is a somewhat strange argument. In the past the rational for export has been tied to the furtherance of domestic Canadian ${ }^{268}$ interests in terms of gas prices, and the development of otherwise dormant reserve areas: particularly because the high concentration of foreign ownership in the petroleum industry tends to limit the extent to which benefits for Canadians can be associated with industry earnings. ${ }^{269}$ If the deliveries, which are for the most part over

\footnotetext{
263 National Energy Board Report to the Governor in Council, 1970, supra, n. 201 at 4-19.

264 National Energy Board, Reasons for Decision, 1971, supra, n. 249 at 5-13

265 In other words as an absolute the rate of discovery has been on the rise, but relatively it has fallen off.

266 National Energy Board, Reasons for Decision, 1971, supra, n. 249 at 6-3.

${ }^{267}$ Id. at 6-1, 6-2. Interestingly, the Board must entertain considerably more doubt than this statement admits to, for in 1970 it was argued that access to oil export markets was the crucial factor vis-a-vis gas discoveries because of the organic relationship between the two. If this is in fact the case then the past approvals of the Board would appear to have secondary importance vis.à-vis discovery incentives. In this regard the 1970 Report, supra, n. 201 at $10-10$, suggested:

It is self-evident that reliable accessibility of export markets for Canadian crude oil would, by encouraging exploration for and development of hydrocarbons in general, improve the prospects of increasing established reserves of gas in Canada. . . . Conversely, the shutting in of reserves of crude oil through restrictions on its access to export markets would automatically shut in associated gas, and would discourage investment in exploration of hydrocarbons.

The Board has not, to the researcher's knowledge studied the proportional contribution of oil exploration and development to Canadian gas reserves, either historically, or what can be exported in the future. A judgment therefore of which factor is more crucial to discovery stimulation (i.e., export approvals or an increase in foreign oil markets) is thus not at present possible to make with complete confidence.

${ }^{268}$ Royalties, because they are imposed at the provincial level, are not considered for the purposes of this analysis.

269 In particular the benefits are confined to the multiplier effects of the exploration, development, and pipeline construction, royalties and license fees, and a heightened corporate tax base. As respects the importance of provincial royalties, the situation of course varies from province to province. In Alberta over 1970 between $20-23 \%$ of the province's revenue derived from gas reserve development on Crown land (i.e., $\$ 218,215,983)$. Over
} 
lines in which exports either are exclusive or dominant, do not serve significant Canadian markets, and fail to generate a rate of discovery that can at least keep pace with the growth in Canadian requirements, then the licenses issued by the NEB did not in fact concern "surplus" gas in the first instance, and second, did not, as matters have turned out, play the part of providing the "encouragement for producing companies to ... explore for more gas in Canada" to the extent that circumstances dictated. All that did occur was the provision of "cash flows," and when all the "ands, ifs, and buts" are removed, it is clear that, in terms of its own imperfect set of demand and supply criteria, a mistake has been made by the Board. Simply put, export needs have been given more priority than they should have vis-ä-vis the rate of expansion of the domestic market, and the best interests of the Canadian public.

\section{Canadian Market Protection With Respect to Price Structures and Quantity Requirements}

Another threatening aspect of the present regulatory stance towards exports concerns the ambivalence shown towards southern reserve depletion's concomitant impact upon first, the rate at which the higher cost northern reserve areas will have to be tapped, and second, the future price at which gas will be sold to the domestic consumer. Dealing with the last point first, the Board appears to have assumed the inevitability of a worsening price situation for the North American market without examining the various means through which the Canadian energy market might insulate itself from the upward price pressures that will be the inescapable consequence of having to rely upon gas from progressively more remote fields. It argued in 1970 that: 270

Energy prices in North America are virtually certain to rise materially, and there is no means apparent by which Canadian consumers of energy can be wholly insulated from such changes.

In adhering to this contention, the regulators have ignored the possibilities that are inherent to a system of reserve-to-market allocations whereby the more attractive southern reserves might be preserved for domestic requirements, leaving the more northernly areas open to the export market. In July of 1965 the Board said that:271

[T] The Canadian natural gas industry, in the years since large quantities of gas became available for marketing outside the original areas of discovery has been characterized by a very rapid pace of development indeed. The Board has no doubt that the ingenuity of enterprise of those in the industry will cause its development to continue at a very substantial rate to broaden out, as has been the pattern in past years, from original areas of prolific discovery in more remote areas, as the establishment of reserves and of markets makes feasible the extension from area to area of the means of transmission of gas from source to market. Recent years have demonstrated that this broadening can be accomplished in such a way that attractive field prices can be paid to producers while unit transmission costs are reduced to an extent which maintains the competitive capacity of Canadian gas in the [foreign] market.

the 25 year period ending 1972 the province had collected a total of $\$ 3.5$ billion revenue from oil leases. See Alberta Department of Mines and Minerals, Alberta Oil and Gas Picture 1947-1969 and 1970 (1970). The Alberta system is incidentally pegged usually at $16 \frac{2}{3}$ percent on gross values at the wellhead so that pricing is of vital concern to the province. This low figure was pegged at an early stage of the industry's development by the Social Credit Government as a possible incentive for growth (re: 1948). Even at that it has been estimated that only 75 percent of present production is subject to royalty charges at the top rate. Acting upon charges that the situation was tantamount to a forfeiture of the region's "birth-right" the newly-elected Conservative Government under Premier Lougheed has been investigating its legal standing to increase provincial receipts. See Toronto Globe \&Mail, April 21, 1972 at B 1. [Editor's Note: See Mineral Taxation Act S.A. 1972, c. 67.]

270 National Energy Board Report to the Governor in Council, 1970, supra, n. 201 at 5-76.

271 National Energy Board Report to the Governor in Council, (1966) at 8-99. 
The logic of this analysis, in terms of the Board's obligation to give priority to the interests of domestic consumers, is faulty on a number of counts. First, to allow the only constraint upon development to be the market price in export areas guarantees (a) that the least expensive gas available will be progressively drawn through the export complexes at the maximum rate that it can be absorbed, and (b) that as it becomes exhausted, production and transmission costs that will have to be outlayed to develop new reserves areas will become progressively higher. Thus as the Canadian market matures, its incremental gas needs will have to be met by ever more expensive throughput (because of both higher development costs and greater transmission distances made necessary by exhaustion due to exports). Second, because long term Canadian gas demands will have to be met with relatively more expensive gas in the future, it implies a real economic loss that has not received "just and reasonable" compensation under existing export price formulas discussed above. It is noteworthy that, while this is a fact of life that appears to have escaped the Board's recognition as part and parcel to its duty in respect of domestic market protection, a number of distribution companies and provinces have been less oblivious to the situation. In 1970 one such interest ${ }^{272}$ suggested to the regulators that: 273

. . the granting of export licences for long terms, with full protection as to supply, tends to dedicate an undue proportion of presently available reserves to export markets, leaving Canadian requirements beyond the relatively short term to be met out of gas yet to be discovered, and probably to come at higher cost from more remote areas. If, once the exporting pipeline transmission systems are going concerns, their increments of export throughput were licenced for relatively short terms, United States and Canadian customers would share more equitably in whatever may be the costs of future increments of supply to be committed to Canadian and export markets.

Carried to its logical conclusion, this argument basically calls for the export market to underwrite more of reserve development costs, and absorb less of Canada's most attractive gas than is true at present. There are four alternate means of accomplishing this objective:

(1) reduce the terms of the export licenses (as suggested above); or

(2) adjust volumes of exports presently licensed directly, leaving license durations unchanged; or

(3) allocate reserve areas to export and domestic markets on a regular basis with the aim of holding Canadian consumer costs to a minimum; or

(4) superimpose a system of discriminatory wellhead price regulation biased in favour of domestic markets.

The first method has limited potential owing to the prevailing capitalfinancing traditions of the pipeline companies that were considered briefly in the discussion of Trans-Canada above. In the past, long-term contracts have been a characteristic of the industry owing to the relatively costly facilities necessary to throughput gas. While the Board announced that it would not consider itself bound by the "conventional wisdom"274 of the industry during its most recent export proceedings, it dared only to reduce license terms to fifteen years. While this is a sizeable reduction relative to the earlier twenty and twenty-five year

${ }^{272}$ Consumers Gas, in the capacity of an intervenor before the Board

273 National Energy Board Report to the Governor in Council, 1970, supra, n. 201 at 6-16.

274 Id. at $10-20-22$. 
license durations, fifteen years from the point of view of attempting to limit export market access to the best gas of southern reserves is still a very long time indeed.

The Board can and will on occasion vary the permitted volumes in an export license from those requested, depending upon its determination of the exportable surplus figure (i.e., a calculus which does not take into account the varying costs of production in acknowledged reserve areas). But ex post facto alterations of either volumes or license duration, permitted under section $17^{275}$ of the Act, for some inexplicable reason have been unequivocally rejected as an option by the Board:276

\begin{abstract}
Although section 17 of the Act enables the Board to review its decisions, and with the approval of the Governor in Council, alter a license issued by it, it is a premise of the Board's approach to the licensing of the export of natural gas that, once a license for firm export for a fixed period has been issued, it should not be diminished in effect or put in jeopardy so long as the conditions of the license are observed. Such reliability of licenses is desirable both in equity to producers, exporters, United States importers and consumers of the gas licensed for export, and in the interest of orderly development of relations between Canada and the United States in respect of natural gas.
\end{abstract}

While the chain of interests drawn out by this statement makes it apparent that regulatory action under section 17 should not be lightly undertaken, it cannot be given the effect of nullifying an explicit statutory provision included under the sovereign authority of the Canadian Parliament, particularly in those cases where an export license, if unchanged, does harm to the public interest which is, when all is said and done, the Board's primary servitude.

The Board, under completely different circumstances, has received argument that it should allocate reserve areas to particular markets, and rejected it. Essentially the Board was asked by Westcoast Transmission to dedicate the California market that is now served by Alberta and Southern to gas from British Columbia sources. The latter company, in conjunction with the Canadian Petroleum Association, argued that the regulators lacked sufficient statutory authority to allocate market areas, and that had Parliament held a contrary intention, given its "broad economic and political implications," it would have specifically referred to it in the Board's constating enactment. ${ }^{277}$ No response was offered in face of this argument, the Board instead claiming that: 278

... it is neither practicable nor desirable to enunciate a general policy regarding 'allocation' of markets in the sense proposed by the Intervenors.

The regulators, in a somewhat contradictory fashion, nevertheless went on to give a number of "policy reasons" that cut against the propriety of a system of allocation of export markets. The most important related to the desire to avoid taking any steps which would:279

... in the long run impair [rather] than assist the orderly and sound development of a gas industry in Canada capable of competing not only in Canadian markets but in those United States markets to which Canadian gas may penetrate.

The question of wellhead price regulation, and the issue of the Board's regulatory jurisdiction to impose such a system were introduced simul-

\footnotetext{
275 Supra, n. 86.

276 National Energy Board Report to the Governor in Council, 1970, supra, n. 201, at 10-8.

${ }^{277}$ National Energy Board, Report to the Governor in Council. In the Matter of the Applications under the National Energy Board Act of Niagara Gas Transmission Ltd., (1960) at 8-28.

278 Id. at 8-29.

279 Id. at $8-30$.
} 
taneously with the allocation of markets controversy in 1965. The Board five years previously, in its first report to the Governor in Council,280 had suggested that it did not consider that it had the required statutory authority appropriate to such a task, and since then has consistently declined to consider being involved in the regulation of field prices. In short, the regulators, by rejecting all of the principal means of controlling the influence that export market service will have upon the future structure of domestic gas prices, have made price increases indeed "inevitable" 281 as they claim.

Attention has already been briefly focused upon the Board's propensity for underestimating the growth of domestic demand for natural gas. This is not just the result of the inadequacies inherent to the objective formulas employed to predict future needs. The Board has also been guilty of equal failings in respect of the more subjective issues concerning the changing patterns of energy demand in favour of gas. To illustrate, in 1971 the regulators belatedly acknowledged a growing shift in this direction as a result of the heightened concern for the protection of the environment, among other things: 282

The evidence of virtually every witness appearing before the Board at this hearing confirmed that requirements for natural gas in Canada are increasing much more quickly than was previously thought, even as recently as August 1970. The reasons include;

1. The growing concern about pollution and the introduction of strict controlling regulations related thereto.

2. The recent increases in the prices of alternate fuels relative to the price of gas.

3. The convenience of using gas once the conversion to it has been made. that: ${ }^{283}$

By way of contrast, the regulators had argued a short year before

... the endeavour to control industrial air pollution will favour the use of natural gas, although probably not to the extent envisaged by some applicants and intervenors. The effect is also deemed likely to be more pronounced over the near term. It seems to the

Board that the suppliers and users of competing fuels will be able to comply with clean air standards given a reasonable period to adjust, and will compete in the longer term for the industrial market about as effectively as they do now (emphasis added).

The Board further has also expressed doubts in any case about formally taking into account the extra value, environmentally-speaking, of natural gas, even on the short term. ${ }^{284}$

\section{Export Pricing and the "Just and Reasonable" Test}

As indicated by the above discussion, the future implications for the domestic market from present export commitments are both significant and complex. By an equal token, the notion of a "just and reasonable" price to apply to export sales that will account for all of the involved

\footnotetext{
280 See generally, National Energy Board, Report to the Governor in Council. In the Matter of the Application under the National Energy Board Act of Trans-Canada Pipe Lines Limited, (1965).

281 Supra, n. 265

282 National Energy Board, Reasons for Decision, 1971, supra, n. 249 at 6-4.

${ }^{283}$ National Energy Board Report to the Governor in Council, 1970, supra, n. 201 at 3-15.

284 In this connection the 1970 decision of the Board expresses, supra, $n$. 201 at 3-15, 3-16, the following opinion: It seems to the Board that the suppliers and users of competing fuels will be able to comply with clean air standards, given a reasonable period to adjust, and will compete in the longer term for the industrial market about as effectively as they do now. ... While not convinced that conversion from coal or oil to gas for the primary purpose of combatting pollution will in the long run prove to be the only or optimum solution to that problem, the Board is required by the statutory obligation to take account of such a use in providing for the reasonably foreseeable requirements of Ontario Hydro and other Canadian users.
} 
opportunity-costs is also a sophisticated problem. But the Board's approach to the question has been somewhat-less-than sophisticated. It has only on one occasion elaborated upon section $83 .{ }^{285}$ In "Reasons for Decision In the Matter of the Application of Westcoast Transmission Company Limited" it set out a test consisting of a three-pronged inquiry:286

(1) Does [the export] recover its appropriate share of the costs incurred by the Canadian transmission company?

(2) Is it not less than the price to Canadian customers of the transmission company in the general area of the proposed export, after allowance for variations in the terms of delivery?

(3) Does it result in prices in the United States market area close to the least cost alternative for energy from indigenous sources?

There are a number of questions that the test does not resolve. First, what standard is applied in the case of a company such as CanadianMontana or Alberta and Southern which exports without serving Canadian customers en route? Second, what is meant by the phrase "appropriate share of costs"? Does this mean that the export revenues should cover all of the facilities necessary for there to in fact be an export, or does it mean that they should be evenly-apportioned between the domestic and foreign markets in proportion with their respective sizes, or does it instead mean that the apportionment should be uneven, with the export market having to account for more than its proportional share of the capital costs of the facilities? In other words, how much is "appropriate"? The history of the Westcoast export has amply demonstrated the point that this question has more than abstract significance. Third, what is meant by "allowances for variations in the terms of delivery," and by what standards are they appraised as "fair" or "unfair" vis- $\dot{a}$-vis cost apportionment? Fourth, what definition of "costs" is to be employed in this test? Does "costs" refer to the economist's notion such that the producing and transmitting enterprises receive a fair return on their investment in the form of profit earnings, or is some accounting definition being contemplated? If it is the latter, perhaps in recognition of the reduced significance of profits vis- $\grave{a}$-vis the public interest, ${ }^{287}$ then should not the Board affirmatively seek lower prices in the Canadian market as a means of ensuring a "real return" for Canadians from the dedication of domestic resources for external ends? And finally, how close is "close" to the least cost alternative in the U.S. market? Is account here taken of the greater total supply limitations which will result in supply price inelasticity if such markets have to depend upon domestic reserves, or is the least cost alternative measured as of the date of export without reference to price structure alterations which would in the absence of an export take place?

It also deserves mention that even in those rare cases where the test can be appropriately applied (i.e., those cases where there is a blended domestic and export market) the Board has not itself followed it. Westcoast is one example. The repeatedly sub-standard export bargains of this company have already been discussed, one of which precipitated the propounding of the test in the first place. And on its face it is evident

\footnotetext{
285 National Energy Board Act, supra, n. 86.

286 February, 1968 at 8.

287 U.S. ownership in 1968 was estimated to be 54 percent and controlled 62 percent of the Canadian Petroleum Industry. See Foreign Ownership and the Structure of Canadian Industry: Report of the Task Force on the Structure of Canadian Industry, (or simply the Watkin's Report (1968) at 422).
} 
that the test has no application with respect to the cost-of-service based exports of Alberta and Southern, and Canadian-Montana.

Finally, despite specific ambiguities noted about the test supra, its notional adequacy is impeachable on more general grounds: namely, it does not aim at a recapturing of the full opportunity-costs of exported gas today that can be used by the domestic market tomorrow. Given that there are now well-developed internal markets that have grown reliant upon natural gas, and that such reliance will over the long term increase both proportionately and absolutely, it is clear that the "on the spot" measurements involved in the Board's formulation are a dangerous oversimplification of what is "just and reasonable" in terms of the "public's best interest". What is required instead is a forward looking benefitcost analytic approach that can take into account such diverse factors as relative price changes as a result of exports and their influence upon future domestic gas utilization, production costs, environmental costs, heating costs, electricity costs, and so on, to name but a few. The benefits of exports in terms of development incentives, the relative value of new finds, the multiplier impact of pipe construction, and the like, also cry out for a critical reappraisal. Without a re-examination of the broader implications, including the ones just enumerated, the regulators are incapable of passing judgment upon the matter that section 83 commands; and are therefore falling short of fulfilling their statutory obligations.

\section{Preservation of the Line Between Integration and Co-operation}

Energy is basic to any industrial society. It is for this reason that, on the international sphere, agreements that involve the transfer of energy producing resources are often highly controversial. This has proven to be particularly true of a number of past dealings between Canada and the United States. The recent Columbia River Treaty and Protocol, ${ }^{288}$ which still remains highly controversial, is perhaps an excellent case in point. Other historical examples such as the Essex County gas exports ${ }^{289}$ referred to earlier, the Niagara Hydro-electric power dispute, 290 and the Waterton and Belly River issue, ${ }^{291}$ might be cited as well. That they have raised so much controversy owes mainly to the thought that, once an agreement is reached, the growth of reliant interests becomes so significant that it is impossible for the exporting country to reverse the flow of the resource. What then is created is, in effect, a permanent appropriation by the importing country that represents a perpetual charge against the sovereign discretion of the exporting nation to employ internal resources as it sees fit.

Unlike the international law in force between Canada and the United States as respects the development of transboundary water resources,

${ }^{289}$ The Columbia River Treaty (1961) and Protocol (1964). This controversy has revolved around three issues: namely, the distribution of power benefits, the opportunities for consumptive diversions as a result of Canadian storages being realized, and the implications of the agreement in terms of trans-boundary water law. See McDougall, The Development of Trans-Boundary Water Law: Development for Mutual Advantage or Continentalism's Thin Edge of the Wedge? 9 Osqoode L.J. 157, and Ripley. The Columbia River Scandal. Engineering and Contract Record, April 1964.

289 See supra, discussion of history of gas exports.

290 In this case Canada had loaned a portion of its share of the generating capacity of the Niagara power development to the United States and found itself unable to reclaim it when industrial energy needs grew during World War One.

291 This case, brought before the International Joint Commission, was notable for the very clear expression of national priority expressed by the United States. Canada as the downstream owner of the rivers in question wished to exploit the irrigation potential which they offered. The United States in turn asserted that such a use would be entirely subject to the possibility of future upstream uses in the United States. See McDougall, supra, n. 288 and Article II, Boundary Waters Treaty, 1909. 
formal argument has not been heard that a doctrine of prior appropriation should apply to the international flow of petroleum energy resources. This perhaps owes to the fact that there is no equivalent to the International Joint Commission that has been given a specific mandate from both countries to deal with the range of petroleum resources that may become objects of trade. ${ }^{292}$ Also, unlike transboundary waters, energy sources, and in particular natural gas, are not usually "shared" resources in the territorial sense of the term. It takes physical effort, and often massive expenditure to make natural gas capable of delivery to another country.

However, it has been argued that the sheer magnitude of the required investments is itself a basis for asserting a prior right: at least to the point that the financial outlays made in reliance have been fully recouped. And it has further, and frequently in the recent past, been contended that energy is part of a "continental resource heritage" rather than a strictly national one. The proposals for a "Continental Energy Package" that have been the subject of discussion ${ }^{293}$ between Canada and the United States of late, appear to begin with the premise that the locus of greatest demand should rule the question of allocation, and further, that the ability to satisfy these demands with alternate energy production modes should rule on the question of conservation, and not national sovereignty. Put briefly, but accurately, the Canadian right to choose how it can best serve the present and future needs of its citizens in respect of natural gas would be subordinated to the more pressing needs of U.S. industrial and population centres. And these needs are almost insatiable. As matters now stand the U.S. has consumed thirtyfive percent of the world's energy. ${ }^{294}$ Ninety-six percent of the country's energy inputs consist of fossil fuels. ${ }^{295}$ So far as natural gas has been concerned, net imports have risen from almost zero in 1960 to more than 4 percent by 1971 , and it is apparent that, without significant breakthroughs ${ }^{296}$ in the efficiency (and safety) of thermonuclear energy production, this external dependence will expand substantially in the future. ${ }^{297}$

Mention has been made of the NEB's deference towards private financing and market commitments, and its unwillingness to change such arrangements by force of its statutory authority when once com-

292 Nor is it suggested that such a body be instituted for from Canada's perspective it would be tantamount to a national acceptance of the argument that its petroleum resources are part of a continental heritage and not that of the national domain. On the other hand a national bargaining agency with none of the "international comity" objectives so necessary to the I.J.C.'s work in respect of boundary water negotiations (i.e., as distinct from trans-boundary issues where national interests divide sharply in many cases) might prove to be an exceedingly valuable innovation. See infra, recommendations and conclusions.

293 The status of these discussions is as of the date of writing far from clear. So too is the precise scope of such a plan.

294 Cook, The Flow of Energy in an Industrial Society, Scientific American, September 1971 at 134.

295 Id. at 135.

296 As of the present moment there is no cause for great optimism in this respect. See Bryerton, Nuclear Dilemma (1970), and Curtis and Hogan, Perils of the Peaceful Atom: The Myth of Safe Nuclear Plant (1970), for a discussion of safety factors, and Clark, Thermal Pollution and Aquatic Life, Scientific American (1969) Vol. 220 , No. 3 at 22 for an elaboration of one of the diseconomies of such plants, and the NEPA (U.S. National Environmental Protection Agency) guidelines vis-d-vis environmental safety standards adopted by the AEC (Atomic Energy Commission) and considered during the recent Calvert Cliffs project con troversy for an indication of the growing trend to internationalize such environmental spillovers (i.e., and thus requiring that an even higher efficiency threshold be obtained in order to justify the construction of such plants). See also, Atomic Breeder Unit Planned in Tennessee. The Toronto Globe and Mail, January 15 1972 at B3 for a summary of the current status of breeder-reaction developments in the Western Hemisphere. It was suggested that operation of even an initial experimental plant could not be reasonably expected in the U.S. until after 1980 at best.

${ }^{297}$ That is to say, assuming access to relatively economic supplies can be obtained by the U.S. 
pleted and approved. The Board's Report to the Governor in Council In the Matter of the Application under the National Energy Board Act of Niagara Gas Transmission also shows that the regulators have at least considered the difficulties that may arise when external interests become wholly reliant upon Canadian gas. It was noted that:298

[A]ny application for the export of gas to areas where Canada would be the sole source of supply tends to emphasize a number of problems which may be relevant but less distinguishable in instances of gas export to areas simultaneously supplied from other sources....

Quoting from one of its earlier reports, the Board contended that wholly dependent markets offer a measure of risk that must be carefully weighed:299

Since, so far as the record indicates Trans-Canada would be the sole source of supply for the area to be served by St. Lawrence [the importing company], acceptance of the present application either would imply acceptance of some responsibility to supply, within a short period and thereafter, additional gas to meet the load growth of the area, or else would imply a rather casual view by the Board of the responsibilities of Canada in commencing a strictly limited supply of gas to a wholly dependent export market. Neither implication is acceptable to the Board.

Despite these reservations the Board issued a license facilitating the desired export on the clear understanding that in so doing Canada, as the exporter, did not intend thereby to assume a perpetual obligation to supply the energy needs of the concerned communities. In answer to their own reservations the regulators observed that the volume of gas involved was rather small, and, in light of the conditions expressed about future deliveries, the arrangement was "unlikely to cause embarrassment either to Canada or the United States". 300

What remains bewildering about this disposition is not the care and attention the Board quite properly took in respect to the possibility of future irreversible dependencies, but that no similar apprehensions were expressed about the relatively enormous exports through Alberta and Southern's 36 inch diameter pipe and those of Canadian-Montana. In both instances, as well as in the license issued to Westcoast in response to the Pacific Northwest's "urgent". energy needs, it was (and is) evident that there are far greater reliances being built around the provision of Canadian gas supplies. And it is also rather clear that the substitution of indigenous sources of production would involve enormous expense and create more problems than would be true if the Niagara license were cancelled.

In the Niagara case the regulators were also at pains to consider ${ }^{301}$ the effects of the resulting energy costs in Northern New York should the export be approved vis-à-vis industrial competition between New York and Ontario. Yet once again, when it came to the much larger export applications referred to above, no consideration of the broader implications in terms of international trade and industrial rivalry were taken

298 National Energy Board, Report to the Governor in Council in the Matter of the Application Under the National Energy Board Act of Niagara Gas Transmission, (1960) at 10.

299 Id. at 8 .

$300 \mathrm{Id}$. at 12.

${ }^{301}$ While the Board devoted some effort to considering this issue, its disposition was less than satisfactory for it was contended, that so long as the U.S. industries affected were not placed in a position that was superior to that of their Canadian counterparts, they would not object to their enjoyment of an equal advantage which, from the standpoint of the enhancement of domestic production and growth is of dubious merit. Nor did the Board consider the possibility of the locational attractiveness that Canada might acquire for industry should gas prices be higher in the export market than domestically. 
under consideration. The divergence between approaches reflected in the Board's handling of large and small export applications is disquietingly inconsistent.

The degree of liaison that may exist between the Canadian and American regulatory agencies is not clear. It is known that joint meetings have been held from time-to-time to consider the more generic issues of energy development that could be the subject of cooperative efforts in the future. ${ }^{302}$ It is less clear whether individual export applications have ever been discussed between the two bodies. There appears to be evidence in both directions. On the negative side, the "pushing and pulling" that occurred between the NEB and FPC over the WestcoastEl Paso renegotiations of Sumas II can be cited. On the affirmative side there is some suggestion that the second Trans-Canada pipe south of the Great Lakes was approved by the FPC in large measure to accommodate Canadian needs rather than American ones.

\section{CONCLUSIONS AND RECOMMENDATIONS}

The "take-off" of the Canadian natural gas industry that was described in Part I was characterized by a certain measure of confusion, and occurred in what might be described as a National policy vacuum, at least as respected exports to the United States. Initially, governmental involvement was preoccupied with the objective of an eastern market served by domestic reserves. Exports had not been a major concern of Canadian policy-makers since the Essex County crisis of some fifty years before. But the great Pipeline debate to some extent rekindled Canadian concern about serving the U.S. gas markets, and it was against this backdrop that the Borden Commission submitted its controversial recommendation in support of sweeping, on-going, centralized regulatory authority over developments in Canada's petroleum industry.

As outlined in Part II, the wide jurisdictional birth right of the National Energy Board was one means of providing the regulators with at least "a fighting chance" in the sense that they were given the latitude to evolve solutions most appropriate to the difficult public interest questions that the Commissioners of the Borden Commission had only generally described. Thus, as well as having broad power, the NEB was placed under an enormous onus to both particularize and protect an ambiguously-defined set of national objectives (i.e., preservation of reserves for domestic markets, promotion of just and reasonable compensation for exported volumes, and so on).

Moreover the Board had to confront an industry of extraordinary intrinsic sophistication, that had been built upon a tradition of risk assumption in face of substantial uncertainty. To some extent the willingness to gamble as the price of uncertain rewards was bound to prove to be an infectious attitude that the regulators would themselves assume, for they, like the industry they controlled, were obliged to protect future interests which entailed as many probabilistic contingencies as did industry profit earnings. The issue of concern to this article has not been that the Board has taken chances, but the extent to which they have done so, and their reasons for it.

An alliance of interest between regulators and regulated was both

302 Cf. Fischer, The Role of the National Energy Board in Controlling the Export of Natural Gas from Canada, 9 Osgoode L.J. 553. 
inevitable and natural for both laboured under common problems. First, both were concerned with obtaining an accurate assessment of Canadian gas reserves. Second, each shared an interest in promoting high rates of discovery and new production. And third, there was a common interest in gauging the future potential of the expanding domestic market, and those factors which were most crucial to its rate of growth. But in addition to the shared interests, the regulators and regulated enjoyed something of a symbiotic relationship for quite another reason. For the industry the Board represented an institutionalized conduit between itself and the formation of governmental policy. For the Board, its close alliance with the various firms provided both data access and a far more intimate acquaintanceship with the critical variables of petroleum resource development than had been achieved previously. Government also profited from this close liaison to the extent that the deceptively-regularized proceedings of the Board proved to be the symbolic reassurance necessary to placate an alarmed public.

The low public profile of the export issue subsequent to the Borden Report left the Board and the industry more or less insulated and free to develop their own compromises. As suggested in Part III, these were rather one-sided in favour of the industry (and in particular the foreign importers) insofar as exports were at issue, but the lack of substantial opposition is not difficult to comprehend. Not many outside of the immediate locus of the decision-process had command of the technical complexities that were being considered, and, in any case, this "technical threshold" itself deterred public access for those few people that had misgivings. Thus both the agreements entered into for export service, and the evolution of regulatory methodology and procedure were questions that were the exclusive province of the Board.

It was argued in Part IV that the Board's standards of accomplishment in face of these environmental conditions appears to be somewhat inadequate vis-à-vis the National interest. A number of problems were considered in this discussion. First, mention was made of the uncertainty of both reserve estimation in the southern producing areas, the refined but rigid methodology employed by the Board, and the conservatism shown by the regulators in respect of domestic market growth; all of which has combined to produce a foreseeable deficit, rising domestic gas prices, and ultimately an earlier obsolescence of natural gas burning energy capital than would otherwise be the case. In this connection the following recommendations might be made:

(1) a reappraisal of existing methods employed to assess reserves with an eye towards reducing that share of the burden of overestimation in terms of quantity and quality (i.e., price) now assumed by domestic consumers present and future;

(2) a freeze upon dedication of new southern reserve pools to U.S. market service with the ambition of (a) reducing the rate of depletion of such areas, and (b) stimulating development in the northern reserve regions that cannot at present be funded by the Canadian gas market;

(3) a public entry into field exploration and discovery in southern areas, possibly on a shared ownership basis as is now true of Panarctic Oils Ltd., in order to offset reductions in exploratory expenditures as a consequence of recommendation (2) supra. 
Second, problems associated with the predominance of foreign-ownership in the natural gas industry, and in particular in respect of export pricing were considered. Closely related to this issue is the degree to which the Board has proven itself willing and/or capable of developing appropriate terms for exports consonant with Canadian best interests, and later refining them should that prove necessary after approval has been given. In this regard the following is suggested:

(4a) enactment of a statutory clarification of the Board's jurisdiction to regulate gas prices at the well-head in respect of gas reserves earmarked for the export market; or

(4b) in the event of a federal-provincial constitutional dispute, a statutory declaration naming all of the export complexes "works" for the General Advantage of Canada under s. 92(10)(c) of the British North America Act, followed by possible price regulation at the border; 303

(5) a comprehensive reappraisal in benefit-cost terms of the economic significance of export market service, having in mind the development of an economic opportunity-cost basis for the "just and reasonable" test;

(6) a clear statement by the Board that it will utilize the power to revise export terms ex post facto in the name of the public interest, followed by a review of the present price provisions in force (in light of the standards that arise from the study of economic costs referred to supra);

(7) the imposition of a mandatory mix of export and domestic market service in respect of those complexes which are today whollyexport-oriented.

Third, at various points in the discussion reference has been made to an assorted number of extra problems, including the role of the public in Board proceedings, the related issue of the visibility and comprehensibility of Board decision-making, and the somewhat uncertain status of large scale energy talks between the U.S. and Canada and their respective regulatory agencies. The following is recommended:

(8) NEB Reasons for Decision should in future contain any dissent within the Board, and at very least a critique of the risks inherent to a decision (i.e., similar to the FPC format where any dissent is recorded) in order to heighten public awareness and discussion;

(9) natural gas should be removed from any discussion of a Continental Energy Package which is, or will be taking place between Canada and the United States.

Cooperative undertakings between Canada and the United States have had a long, and often successful history. This tradition, however, has not been built upon the mere dictates of "amity and comity" so often mentioned in the Board's decisions. It has instead arisen from a full cognizance by each party that the respective advantages possible can often be enhanced through joint effort. This, it is argued, is a far firmer foundation for good relations than a somewhat hollow phrase which future generations of energy consumers might well resent. A more appropriate catch phrase for Canadian regulators might now well be "good fences make good neighbours" where Canadian natural gas is concerned.

${ }^{303}$ See Appendix A for discussion of s. 92(10)(c) and General Advantage declarations 


\section{APPENDIX A}

\section{FEDERAL JURISDICTION AND THE GENERAL ADVANTAGE CLAUSE}

As a matter of law there exists a means through which a strictly intraprovincial resource development can be brought within the ambit of federal control. At issue here is the declaratory power under s. 92(10)(c) of the B.N.A. Act. Because this provision has relevance to the discussion in the text, and the subsequent conclusions, it will be considered in some detail here.

The wording of this provision is broad in the extreme: ${ }^{304}$

92. In each province the legislature may exclusively make laws in relation to matters coming within the classes of subject next hereinafter enumerated; that is to say, ...

10. Local Works and Undertaking other than such as are of the following classes:

(c) Such works as, although wholly situate within the province, are before or after their

Execution declared by the Parliament of Canada to be for the general advantage of Canada or for the advantage of two or more of the provinces (emphasis added).

The power inherent to this section, it can be seen, is limited at law (and for the moment putting aside considerations of practical political diplomacy between Parliament and the Provinces) only by the definition of the word "work". This term has been the subject of some judicial confusion. Duff J., for example, in the Reference re Waters and Water Powers case $\mathrm{e}^{305}$ referred to "works and undertakings" despite "undertakings" not being part of the actual section. In this connection Laskin J. has noted a reticence on the part of the courts to explore the limitations that are implicit to the term "work" too deeply. He does however note that a number of points do nevertheless emerge more or less as clear rules from the cases. ${ }^{306}$ It is for example probably settled law that, in order to be valid, a declaration must have the force of statute, and in this regard a mere recital or preamble reference will not suffice. ${ }^{307}$ Furthermore, the work itself must be specifically noted within the legislation, or be otherwise an integral part of the declared work to be included at law. ${ }^{308}$ In addition, when Canada attempts to declare jurisdiction with regard to a class of works unrealized as of the date of the declaration, the terms of the statute will have to offer both precision and be couched in compelling language in order for the courts to overcome the problems that may be raised in respect of their identification. ${ }^{309}$

So far as judicial interpretation is concerned, it is significant that the language of the cases ${ }^{310}$ strongly suggests that, apart from the few factors above, the declaration itself is probably unreviewable. The power

\footnotetext{
304 Driedger, A Consolidation of the British North America Acts, 1867 to 1965, (1967)

${ }^{305}$ [1929] S.C.R. 200.

${ }^{306}$ Laskin, Canadian Constitutional Law: Cases, Text and Notes on Distribution of Legislative Power, 504-505 (3d. ed., 1969).

${ }^{307}$ Cf. St. John and Quebec Ry. Co. v. Jones, (1921) 62 S.C.R. 92; Luscar Collieries Ltd. v. McDonald [1925] S.C.R. 460, aff'd [1927] A.C. 925 .

${ }^{308}$ Cf. Wilson v. Esquimalt and Nanaimo Ry. [1922] 1 A.C. 202.

${ }^{309}$ Supra, n. 307.

310 E.g., Mignault J.'s judgment in the Luscar Collieries case (supra, n. 307), contains statements such as "[p]arliament is the sole judge of the advisability' of making [a] declaration as a matter of policy and . . the policy or the reasons for the declaration is a matter for the consideration of parliament alone." Laskin in his text (supra, n. 306) has argued that, while the courts can undoubtedly review what constitutes a "work", they cannot concern themselves with the wisdom of the policy reasons lying behind the declaration.
} 
is therefore a sweeping one. It remains, however, to explore first, why Canada might wish to make a General Advantage declaration in the case of a purely intra-provincial project, and second, what such a declaration accomplishes.

With respect to the first of the points, it can be well-contended that the notion of a purely intra-provincial petroleum resource development is often a fiction. At issue to such development is the attaining of the optimum advantages possible from the resource. Natural gas as a primary asset is a transportable commodity while the provinces tend to view only those development alternatives which localize the flow of benefits within their own jurisdiction. In many cases optimum development from the national point of view may require the sacrifice of one or more of these options. An analogous case which was recently the subject of much debate in Canada concerned the possibilities for extra-provincial development of the Columbia-Kootenay rivers complex. It was argued repeatedly ${ }^{311}$ that by far the greatest potential to a combined ColumbiaKootenay development lay in the ultimate delivery of water to the eastern slope of the Rockies for power and consumptive purposes. The economic merits of this proposal remain today a matter of some controversy, but in any case they are, as matters stand, a somewhat academic point, for British Columbia was strongly opposed to the suggestion that any of its waters should be re-routed to the benefit of the Prairies.

Assuming for the moment that the proponents of the combined hydroelectric consumptive diversion at Surprise Rapids were correct, then it is submitted that the Columbia River development would have been a model case for a 92(10)(c) declaration. It was a circumstance involving rivers which, while they were trans-boundary, were from the point-ofview of the other provinces, intra-jurisdictional to the Province of British Columbia. If the narrow attitude taken by that Province about development were to in fact mean that a superior alternative, from the point of view of the economy as a whole, had to be forfeited, federal initiative would be more than justifiable. Extrapolating from this example, it is argued that consideration should be given to the declaratory power whenever the economic rewards of a particular project can be expanded so as to affect the affairs of neighbouring provinces and/or the country as a whole.

The rationale here can be analogized to that employed with reference to the proposed erosion of the private industrial rights over the development of petroleum reserves unimpeded by regulatory control over prices and guarantees when once given the sanction of an export license. Just as the industry should be unable to reserve rights of use at the expense of the economy-at-large, neither should provinces, if it entails foregoing the attainment of maximum development benefits for the country-at-large.

Supposing that such a declaration is made, it then becomes pertinent to consider its impact at law. As a first point it must be noted that, merely because Canadian jurisdiction has been assumed, it does not follow that ownership in the concerned works has thereby been transferred. The effect of the declaration relates merely to the issue of control, and not ownership. However, it may be possible for Parliament to exer-

31 See e.g., Submission to the House of Commons Standing Committee on External Affairs by the Government of Saskatchewan on the Columbia River Treaty, (1964). 
cise its powers of expropriation given that the works have been brought in juris. Assuming that none of the problems with respect to statutory precision as to the concerned works referred to above arises, pipelines would be amenable to a General Advantage declaration. Control would then vest not only as it concerned the particular physical projects in issue, but their operation as well. ${ }^{312}$

But while, as a matter of law, the federal declartory power could conceivably play an important role here, it is important to stress that the assertion of this power is, to say the very least, an extreme and controversial exercise, and it is possibly of value to consider other avenues through which Canada might extend its influence over the development of an industrial structure better suited to the domestic interest.

312 "Work" in other words is used in its functional sense. Cf. The Queen v. Thurnbut (1959) 20 D.L.R. (2d) 335. They can include a wide range of things. For example, elevators and mills have been so declared, as has atomic energy development. The term has been construed so as to include a commercial enterprise. Cf. Locke J. in the Stevedoring case [1955] S.C.R. 529. 
APPENDIX B

GRAPHS, MAPS AND TABLES

I

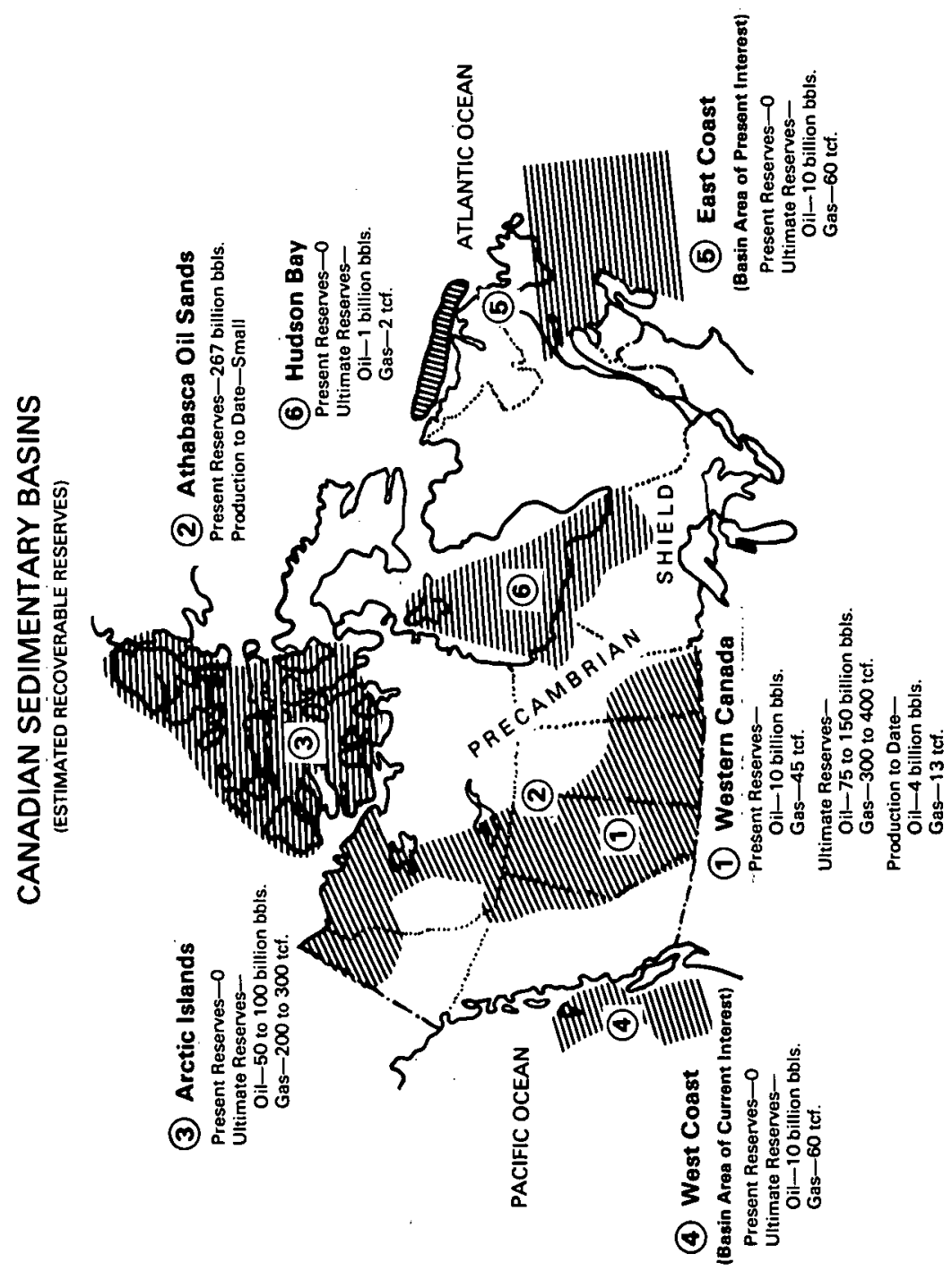




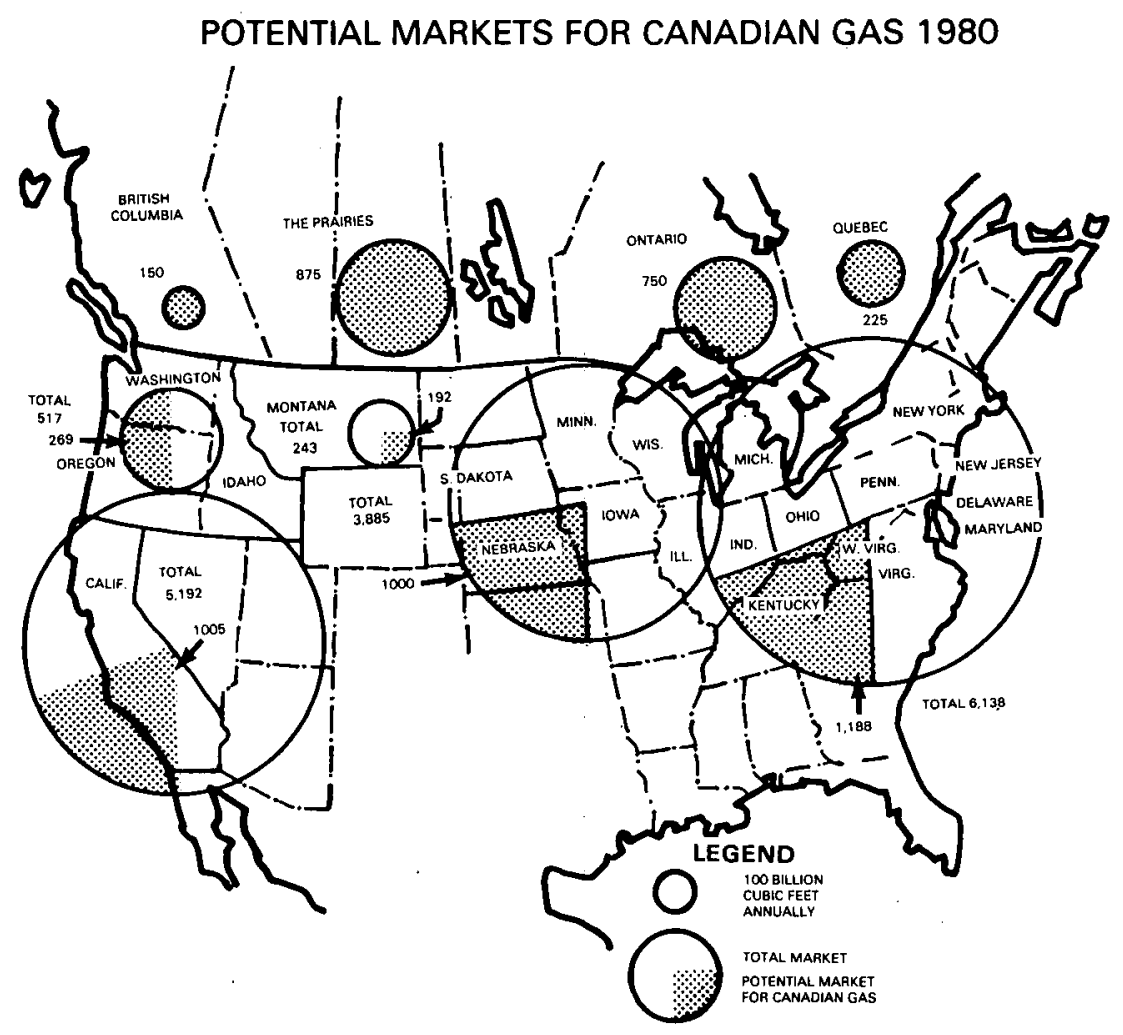


III

\section{The Orders in Council}

\section{P.C. $1957-1386$}

Certified to be a true copy of a Minute of a Meeting of the Committee of the Privy Council, approved by His Excellency the Governor General on the 15th October, 1957.

The Committee of the Privy Council have had before them a report from the Right Honourable John George Diefenbaker, the Prime Minister, representing:

That, in as much as Canada has within its boundaries large sources of energy in the form of gas, oil, coal, water and uranium, the increasing need of energy for the growing industrial requirements of Canada renders it of the greatest importance to assure the most effective use of those resources in the public interest;

That it is desirable that an investigation be made now into a number of questions relating to sources of energy in order to assist in determining the principles and procedures to be applied in the administration of certain aspects of energy policy which fall within the jurisdiction of the Parliament of Canada; and

That it is desirable that a suitable form of organization be devised to ensure that present and future Canadian requirements for energy are taken fully and systematically into account in granting licenses for the export of energy or sources of energy.

The Committee, therefore, on the recommendation of the Prime Minister advise that:

Henry Borden, Esquire, C.M.G., Q.C., of the City of Toronto,

J. Louis Levesque, Esquire, of the City of Montreal,

George Edwin Britnell, Esquire, of the City of Saskatoon,

Gordon G. Cushing, Esquire, of the City of Ottawa,

Robert D. Howland, Esquire, of the City of Halifax, and

Leon J. Ladner, Esquire, Q.C., of the City of Vancouver

be appointed Commissioners under Part I of the Inquiries Act, to enquire into and make recommendations concerning:

(a) the policies which will best serve the national interest in relation to the export of energy and sources of energy from Canada;

(b) the problems involved in, and the policies which ought to be applied to, the regulation of the transmission of oil and natural gas between provinces or from Canada to another country, including, but without limiting the generality of the foregoing, the regulation of prices of rates to be charged or paid, the financial structure and control of pipeline corporations in relation to the setting of proper prices or charges, and all such other matters as it is necessary to enquire into and report upon, in order to ensure the efficient and economical operation of pipelines in the national interest;

(c) the extent of authority that might best be conferred on a National Energy Board to administer, subject to the control and authority of parliament, such aspects of energy policy coming within the jurisdiction of Parliament as it may be desirable to entrust to such 
a Board, together with the character of administration and procedure that might best be established for such a Board;

(d) whether, in view of its special relationship to the Northern Ontario Pipeline Crown Corporation and the nature of its financing and control, any special measures need be taken in relation to Trans-Canada Pipe Lines, Limited in order to safeguard the interest of Canadian producers or consumers of gas; and

(e) such other related matters as the Commissioners consider it necessary to include in reporting upon those specified above.

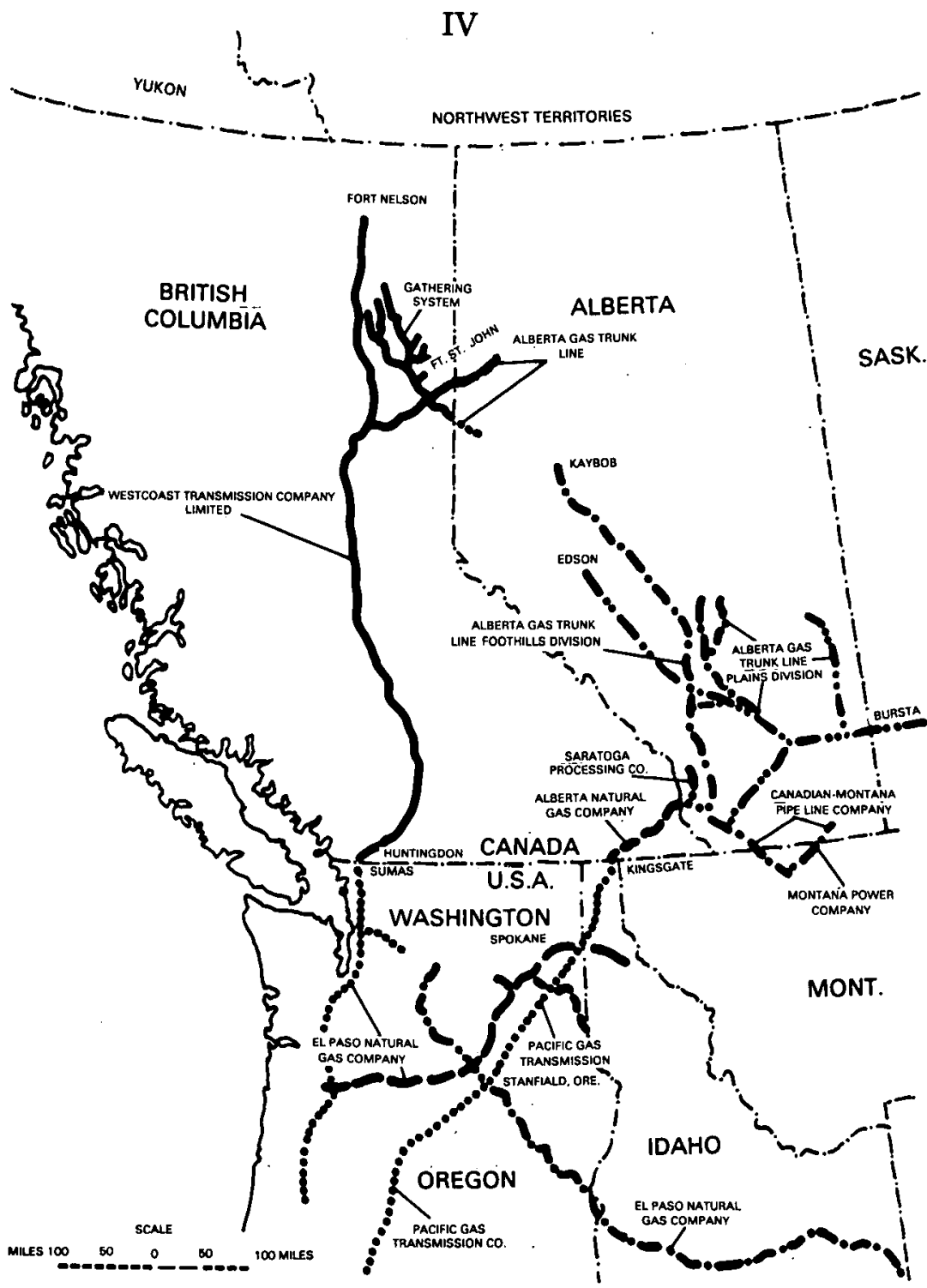

